\title{
Immunotherapeutic interventions of Triple Negative Breast Cancer
}

\author{
Zehuan $\mathrm{Li}^{1,2}$, Yiran Qiu ${ }^{1,2}$, Weiqi Lu ${ }^{1,2}$, Ying Jiang ${ }^{1,2^{*}}$ and Jin Wang ${ }^{2^{*}}$ (I)
}

\begin{abstract}
Triple Negative Breast Cancer (TNBC) is a highly heterogeneous subtype of breast cancer that lacks the expression of oestrogen receptors, progesterone receptors and human epidermal growth factor receptor 2 . Although TNBC is sensitive to chemotherapy, the overall outcomes of TNBC are worse than for other breast cancers, and TNBC is still one of the most fatal diseases for women. With the discovery of antigens specifically expressed in TNBC cells and the developing technology of monoclonal antibodies, chimeric antigen receptors and cancer vaccines, immunotherapy is emerging as a novel promising option for TNBC. This review is mainly focused on the tumour microenvironment and host immunity, Triple Negative Breast Cancer and the clinical treatment of TNBC, novel therapies for cancer and immunotherapy for TNBC, and the future outlook for the treatment for TNBC and the interplay between the therapies, including immune checkpoint inhibitors, combination of immune checkpoint inhibitors with targeted treatments in TNBC, adoptive cell therapy, cancer vaccines. The review also highlights recent reports on the synergistic effects of immunotherapy and chemotherapy, antibody-drug conjugates, and exosomes, as potential multifunctional therapeutic agents in TNBC.
\end{abstract}

Keywords: Triple Negative Breast Cancer, Immunotherapy, Chemotherapy, Antibody therapies, Exosome

\section{Background}

Tumours can be controlled by the immune system. This has been the subject of research for over a century, from the existence of tumour antigens and the cancer immunosurveillance hypothesis to the immunoediting hypothesis [1]. According to the cancer immunoediting hypothesis, tumour fate is shaped by the host immune system through three phases: the elimination, equilibrium and escape phases. The immune balance is first tilted to anti-tumour immunity in the elimination phase, and an intact and competent immune system detects and then destroys the developing tumour during immunosurveillance. Sporadic tumour cells may survive this editing phase and progress to the equilibrium phase, where the balance lies between anti-tumour and tumour-promoting factors, resulting in a functionally suppressed state of the

\footnotetext{
*Correspondence: jiang.ying3@zs-hospital.sh.cn; wangjin@shaphc.org ${ }^{1}$ Department of General Surgery, Zhongshan Hospital, Fudan University, 180 Fenglin Road, Xuhui District, Shanghai 200032, People's Republic of China

${ }^{2}$ Shanghai Public Health Clinical Center, Fudan University, 2901 Caolang Road, Jinshan District, Shanghai 201508, People's Republic of China
}

tumour. Finally, the tumour cells acquire the ability to circumvent immune surveillance and destruction, and these immunologically sculpted tumours emerge with a progressively outgrowing status, establishing an immunosuppressive tumour microenvironment (TME) in the escape phase $[1,2]$.

It is not only infection-derived immunity, immune deregulation and autoimmunity preceding tumour development but also the intrinsic inflammation triggered by malignancies following tumour development that promotes cancer development and progression. As a result of these different forms of inflammation, the TME contains innate immune cells [macrophages, neutrophils, mast cells, myeloid-derived suppressor cells (MDSC), dendritic cells (DCs), and natural killer (NK) cells] and adaptive immune cells ( $\mathrm{T}$ and $\mathrm{B}$ lymphocytes), in addition to the cancer cells and the surrounding stroma (fibroblasts, endothelial cells, pericytes, and mesenchymal cells) [3]. At the same time, inflammation also influences the host immune response to tumours and can be used in cancer immunotherapy and chemotherapy [3]. The immune response in tumours mainly relies on adaptive 
immunity, usually focusing on $\mathrm{T}$ cell-mediated cellular immunity [4]. CD8 ${ }^{+} \mathrm{T}$ cells evolve and kill tumour cells by excreting perforin, granzymes and IFN- $\gamma$ [5]. There is evidence that some immune cells [DCs, MDSC, B cells, $\mathrm{CD}^{+}, \mathrm{CD} 4^{+}$Th1, CD4 ${ }^{+}$Th17, $\mathrm{CD} 4^{+}$Tregs (regulatory $\mathrm{T}$ cells), macrophages, and neutrophils] exert both antitumourigenic and pro-tumourigenic effects and that others exert only pro-tumourigenic effects (mast cells, CD $4^{+}$ Th2 cells) but that NK cells lack a protumourigenic effect [3]. DCs found in the TME play an important role in the induction of anti-tumour responses by cross-presenting antigens to $\mathrm{CD}^{+}$and $\mathrm{CD} 8^{+} \mathrm{T}$ cells [6]. While Tregs normally act against autoimmune diseases by suppressing self-reactive $\mathrm{T}$ cells, in the TME, they block anti-tumour responses by suppressing immune cells, such as $\mathrm{CD} 8^{+} \mathrm{T}$ cells, NK cells and DCs, and even participating in metastasis [7]. The depletion of Tregs in tumours by intratumoural NK cells, macrophages and neutrophils swings the immune balance towards a $\mathrm{CD}^{+} \mathrm{T}$ cell effector function, resulting in tumour suppression and regression [8]. Therefore, augmenting the anti-tumourigenic effect of $\mathrm{CD}^{+} \mathrm{T}$ cells, DCs and NK cells and minimizing the protumourigenic effect from Tregs may serve as potential immunotherapies similar to adoptive cell therapy (ACT). Moreover, the contents of the extracellular matrix (ECM), such as MMPs, prevalently change their activity and show an association with cancer progression and thus serve as potential immunotherapeutic targets [9]. Tumour antigens comprise tumour-associated antigens (TAA) and tumour-specific antigens (TSA), which can be used to specifically detect neoplasms [4]. These antigens, especially TSA, can be harnessed as candidates for tumour-specific antibody treatments, chimeric antigen receptor cell therapies or antibody-drug conjugates to accurately target tumours. Still, there are many sophisticated mechanisms that regulate this process, such as the autocrine effect of $\mathrm{T}$ cells, and we should concentrate on the aspect that is helpful to tumours by way of immunotherapy. Initial theories suggested that breast cancer (BC) is a non-immunogenic disease with fewer immunogenic tumour antigens [10], so BC has not been considered a cancer amenable to immunotherapeutic approaches for a long time; however, recent studies have shown evidence of significant immune cell infiltration of tumour-infiltrating lymphocytes (TILs) in a subset of patient tumours and a consolidated understanding that Triple Negative Breast Cancer (TNBC) is a highly heterogeneous breast cancer subtype, with higher expression levels of PD-L1 and more TILs. The TIL score can be a prognostic and predictive marker in standard therapies. High numbers of TILs correlate with increased pathological complete responses to neoadjuvant chemotherapy in TNBC, which demonstrates that the immune system plays an active role in the subgroup of breast cancer [11].

\section{Triple Negative Breast Cancer and clinical treatment for TNBC}

Breast cancer is categorized into two types: non-invasive and invasive. Clinically, $\mathrm{BC}$ is also divided into three types: hormone receptor positive $\mathrm{BC}$, human epidermal growth factor receptor 2 (HER2) positive BC and TNBC. As an invasive breast carcinoma, TNBC is defined by the absence of the three main breast cancer biomarkers, namely, the lack of the expression of oestrogen receptors (ERs), progesterone receptors (PRs) and HER2. According to its molecular heterogeneity, TNBC is divided into six subclasses, including basal-like (BL1 and BL2 of basal or myoepithelial origin), mesenchymal-like (M), mesenchymal stem-like (MSL), luminal androgen receptor expression (LAR), immunomodulatory (IM) and an unstable type [12]. Representing $10-20 \%$ of breast carcinomas, TNBC has a greater heterogeneity, for which specific therapies have not long been available, and it has a worse survival rate compared to other subtypes [13].

The lack of the identification of driver alterations that can be targeted, such as for traditional anti-Her2 therapy and endocrine therapy, leads to TNBC having a poorer prognosis than other invasive breast cancers [14]. Treatment options for TNBC are at the forefront of clinical research on breast cancer. Currently, TNBC patients undergo combination therapies, consisting of surgery, radiation, chemotherapy, newly developed targeted therapy and immunotherapy. The locoregional treatment of TNBC includes lumpectomy, breast-conserving surgery, total mastectomy and radiation therapy to the whole breast with or without a boost [15]. While some scientists maintain that TNBC requires an aggressive locoregional surgical option, necessarily removing all the breast tissue, emerging studies show that conservation therapy might improve locoregional outcome [16, 17]. Adjuvant/ neoadjuvant chemotherapy is the mainstay of treatment for TNBC; the regimens include administering anthracyclines, taxanes, and/or platinum compounds, dose-dense AC (doxorubicin/cyclophosphamide) and TC (docetaxel/ cyclophosphamide). Although TNBC is sensitive to chemotherapy, conventional chemotherapy options are far from satisfactory. However, the addition of platinum to standard chemotherapy could increase the proportion of patients achieving a pathologic complete response [18, 19]. Radiation therapy should follow chemotherapy when indicated; this is composed of whole breast radiation, chest wall radiation, regional nodal radiation and accelerated partial breast irradiation [20]. For years, TNBC was not typically considered as a cancer amenable for immunotherapy, until recent studies demonstrated several 
promising immunotherapeutic agents and the immune signature [21, 22]. TNBC is divided into five immune subtypes based on four distinct expression signatures, including $\mathrm{T} / \mathrm{B}$ cell, interferon gamma (IFN- $\gamma$ ), transforming growth factor beta (TGF- $\beta$ ), and core-serum response, DCs, and/or macrophages (CSR), namely, T/Bcell/IFN high, IFN/CSR high, CSR high, TGF $\beta$ high, and immune low [22], which are the specific molecular signatures for the immune heterogeneity of TNBC and put immunotherapeutic interventions on the table for TNBC.

\section{Novel therapies for cancer and immunotherapy for TNBC}

Currently, immunotherapy is emerging as an exciting treatment option for TNBC patients. In general, cancer immunotherapy encompasses immune checkpoint inhibitors and cytokines, adoptive cell therapy, and cancer vaccines.

\section{Immune checkpoint inhibitors}

Anti-PD-1 antibodies (Pembrolizumab, JS001, PDR001, and Nivolumab) and anti-PD-L1 antibodies (Atezolizumab and Durvalumab)

Programmed cell death protein 1 (PD-1) is an inhibitory immune checkpoint inhibitor that limits T-cell effector function within tissues, and it is expressed on the surfaces of immune effector cells, such as T-cells, B cells, NK cells, DCs, and many TILs [23], and has two known ligands, namely, PD-L1 and PD-L2 [24, 25]. PD-1 expression can be induced by tumour-derived IL-18 on immunosuppressive CD56 (dim) CD16 (dim)/-NK cells, and tumour-derived IL-18 is associated with a bad prognosis in patients with TNBC [26]. PD-1 can be activated mainly by PD-L1 (programmed cell death protein 1 ligand), which is expressed on T cells, B cells, NK cells, macrophages, DCs, epithelial cells, and vascular endothelial cells upon IFN- $\gamma$ stimulation [27]. As critical inhibitory regulators, the PD-1/PD-L1 interactions in normal tissues can protect against tissue damage and limit inflammatory reactions mediated by $\mathrm{T}$ cells and other immune system components during infections [28]. Tumour cells also express PD-L1 and inhibit T cell responses by upregulating and binding PD-L1 to PD-1 on activated T cells, leading to immune exhaustion and downregulation of the local immune response [29]. Increased PD-L1 expression is seen on the surface of TNBC cells and has functional consequences on $\mathrm{T}$ cells, including decreasing their proliferation and increasing apoptosis, which provides the rationale for implementing therapeutic strategies targeting the PD-1/PD-L1 axis to unleash the effective killing of the TNBC cells [30-32].

Phase I studies evaluating antibodies targeting either PD-1 or PD-L1 show that these agents elicit durable, objective responses in patients with melanoma, NSCLC and renal-cell carcinoma [33, 34]. The first regulatory approved PD-1 inhibitor, Nivolumab, was launched for the treatment of unresectable melanoma in July 2014 [35]. With respect to TNBC, the Pembrolizumab, JS001, PDR001, and Nivolumab humanized anti-PD-1 monoclonal antibodies are currently being tested in multiple clinical trials. The anti-PD-L1 monoclonal antibodies Atezolizumab and Durvalumab are also yielding promising results [36]. The glycosylation of PD-L1 was recently found to be essential for the interaction of PD-L1/PD-1, and a newly developed antibody, STM108, which targets glycosylated PD-L1 (gPD-L1), can induce PD-L1 internalization to the lysosomes and degradation [37].

Although the anti-PD-1 and anti-PD-L1 mAbs have emerged as being of noteworthy significance in $\mathrm{BC}$ treatment, both were recently described as unsatisfactory as single therapeutic agents [38]. Tumour expression of PD-L1 may serve as a potential biomarker for clinical benefit. It was reported that high expression of either PD-1 or PD-L1 correlated with increased Foxp3 ${ }^{+}$Treg infiltration, and PD-1/PD-L1 and Tregs may work synergistically in immune evasion $[39,40]$. Pembrolizumab did not affect the levels of Foxp3 ${ }^{+}$Tregs or change their phenotype or function but did block signalling via the PD1/ PD-L1 axis in activated T cells [41]. Whether anti-PD-L1 $\mathrm{mAb}$ could affect Treg function remains unknown, but it might be a better choice than PD-1 blockade since PD-L1 is expressed on tumour cells while PD-1 is expressed on immune cells. However, not all PD-L1-expressing tumours respond to anti-PD-1/PD-L1 mAbs and it is noteworthy that some PD-L1-negative tumours such as PD-L1-negative lung cancer can respond to these agents [42]. To validate whether targeting PD-1 or PD-L1 is an option for treating TNBC, Pembrolizumab/Atezolizumab, used in neoadjuvant/adjuvant/metastatic settings in TNBC treatment, will be evaluated in ongoing clinical trials in Phase III studies (Table 1). Therefore, targeting PD-1 or PD-L1 may be an option for TNBC, and the efficacy of these immune checkpoint inhibitors remains to be improved.

\section{Anti-CTLA-4 antibodies (Ipilimumab and Tremelimumab)}

Cytotoxic T lymphocyte-associated protein 4 (CTLA-4) is a T-cell inhibitory receptor that is expressed on activated $\mathrm{CD}^{+} \mathrm{T}$ cells and $\mathrm{CD} 4^{+}$regulatory $\mathrm{T}$ cells that express CD25 and Foxp3. CTLA-4, as a homologue of CD28, attenuates the T-cell immune response by binding to both CD80 (B7-1) and CD86 (B7-2) on DCs with affinities much greater than CD28, but the mechanism is unclear [43]. Therefore, CTLA-4 blockade probably removes inhibitory signals in the costimulatory pathway, resulting in the enhanced rejection of the tumour 
Table 1 Ongoing clinical trials of immunotherapeutic interventions of TNBC

\begin{tabular}{|c|c|c|c|c|c|}
\hline Targets/types & Drug & Patient population & Recruitment & Phase & ClinicalTrials. gov ID \\
\hline \multicolumn{6}{|c|}{ Clinical trials in the neoadjuvant setting } \\
\hline \multirow[t]{5}{*}{ PD-1 } & Pembrolizumab & TNBC & Recruiting & $\|$ & NCT03145961 \\
\hline & & & & III & NCT03036488 \\
\hline & & & Active, not recruiting & $\mathrm{lb}$ & NCT02622074 \\
\hline & & & Not yet recruiting & $\|$ & NCT03289819 \\
\hline & PDR001 & TNBC & Recruiting & $\|$ & NCT02938442 \\
\hline \multirow[t]{6}{*}{ PD-L1 } & Atezolizumab & TNBC & Not yet recruiting & III & NCT03197935 \\
\hline & & & Recruiting & III & NCT03281954 \\
\hline & & & & III & NCT02620280 \\
\hline & & & & $\|$ & NCT02530489 \\
\hline & Durvalumab & TNBC & Recruiting & $\|$ & NCT02685059 \\
\hline & & & & $|/| \mid$ & NCT02489448 \\
\hline PD-L1, PARP & Atezolizumab, Veliparib & TNBC, BRCA1/2 mutated, other BCs & Recruiting & $\|$ & NCT02849496 \\
\hline VEGF-A & Bevacizumab & TNBC & Recruiting & $\|$ & NCT02456857 \\
\hline \multirow[t]{2}{*}{ EGFR } & Panitumumab & TNBC & Recruiting & $\|$ & NCT02593175 \\
\hline & & TN-IBC & Recruiting & $\|$ & NCT02876107 \\
\hline \multirow[t]{4}{*}{$\mathrm{ACT}$} & DC & $\mathrm{BC}$ & Recruiting & $|/| \mid$ & NCT03450044 \\
\hline & ү $\mathrm{T}$ cells & $\mathrm{BC}$ & Recruiting & $|/| \mid$ & NCT03183206 \\
\hline & DC-CIK & $B C$ & Active, not recruiting & $\|$ & NCT02491697 \\
\hline & ROR1 + CAR-T cells & TNBC, BCs, Leukemia, Lymphoma & Recruiting & । & NCT02706392 \\
\hline \multirow[t]{3}{*}{ Vaccine } & DC vaccine & TNBC and other BCs & Recruiting & $|/| \mid$ & NCT02018458 \\
\hline & Neoantigen DNA & TNBC & Recruiting & 1 & NCT03199040 \\
\hline & PVX-410 & TNBC & Recruiting & । & NCT02826434 \\
\hline \multicolumn{6}{|c|}{ Clinical trials in the adjuvant setting } \\
\hline \multirow[t]{2}{*}{ PD-1 } & Pembrolizumab & TNBC & Recruiting & III & NCT03036488 \\
\hline & & TNBC and other BCs & Recruiting & III & NCT02954874 \\
\hline PD-1, PARP & Pembrolizumab, Niraparib & TNBC, OC & Recruiting & $|/| \mid$ & NCT02657889 \\
\hline \multirow[t]{2}{*}{$\mathrm{ACT}$} & NK cells & $\mathrm{BC}$ & Recruiting & $|/| \mid$ & NCT02844335 \\
\hline & DC-CIK & TNBC, HCC, RCC, UBC, CRC, NSCLC & Recruiting & $|/| \mid$ & NCT02886897 \\
\hline Vaccine & PVX-410 & TNBC & Recruiting & 1 & NCT02826434 \\
\hline \multicolumn{6}{|c|}{ Clinical trials in the metastatic setting } \\
\hline \multirow[t]{15}{*}{ PD-1 } & Pembrolizumab & TNBC & Active, not recruiting & III & NCT02555657 \\
\hline & & & & $\|$ & NCT02447003 \\
\hline & & & Recruiting & III & NCT02819518 \\
\hline & & & & $\|$ & NCT02768701 \\
\hline & & & & $\|$ & NCT02755272 \\
\hline & & & & $|/| \mid$ & NCT02734290 \\
\hline & & & & $|\mathrm{b} /| \mid$ & NCT01676753 \\
\hline & & & Not yet recruiting & $\|$ & NCT03121352 \\
\hline & & $\mathrm{TNBC}, \mathrm{IBC}$ & Not yet recruiting & $\|$ & NCT03184558 \\
\hline & Nivolumab & TNBC & Recruiting & $\|$ & NCT03316586 \\
\hline & & & & $\|$ & NCT02499367 \\
\hline & JS001 & TNBC & Not yet recruiting & । & NCT03251313 \\
\hline & & & Recruiting & । & NCT03151447 \\
\hline & PDR001 & TNBC, NSCLC, TC, Melanoma & Recruiting & $\mid \mathrm{b} / \mathrm{|l}$ & NCT02404441 \\
\hline & & TNBC, CRC, NSCLC & Recruiting & । & NCT02890069 \\
\hline
\end{tabular}


Table 1 (continued)

\begin{tabular}{|c|c|c|c|c|c|}
\hline Targets/types & Drug & Patient population & Recruitment & Phase & ClinicalTrials. gov ID \\
\hline \multirow[t]{7}{*}{ PD-L1 } & \multirow[t]{5}{*}{ Atezolizumab } & \multirow[t]{5}{*}{ TNBC } & Not yet recruiting & $\|$ & NCT03164993 \\
\hline & & & Active, not recruiting & III & NCT02425891 \\
\hline & & & \multirow[t]{3}{*}{ Recruiting } & III & NCT03125902 \\
\hline & & & & Ib/II & NCT02708680 \\
\hline & & & & $11 \mathrm{~b}$ & NCT01898117 \\
\hline & Durvalumab & TNBC & Recruiting & $|/| \mid$ & NCT02628132 \\
\hline & Avelumab & TNBC, SCCHN, SCLC, NSCLC, Melanoma, & Recruiting & |b/II & NCT02554812 \\
\hline CTLA-4 & Tremelimumab & TNBC, UBC, PDAC & Active, not recruiting & $\|$ & NCT02527434 \\
\hline PD-L1, CTLA-4 & Durvalumab, Tremelimumab & TNBC, SCCHN, SCLC, GEJ, PDAC, ESCC & Recruiting & $\mathrm{lb}$ & NCT02658214 \\
\hline PD-1, PARP & Pembrolizumab, Niraparib & TNBC, OC & Recruiting & $|/| \mid$ & NCT02657889 \\
\hline \multirow[t]{3}{*}{ PD-L1, PARP } & Durvalumab, Olaparib & TNBC & Recruiting & $\|$ & NCT03167619 \\
\hline & Durvalumab, Olaparib/Cediranib & TNBC, OC, CRC, NSCLC, SCLC, CRPC & Recruiting & $|/| \mid$ & NCT02484404 \\
\hline & Atezolizumab, Veliparib & TNBC, BRCA1/2 mutated, other BCs & Recruiting & $\|$ & NCT02849496 \\
\hline VEGF-A & Bevacizumab & TNBC and other BCs & Active, not recruiting & $\|$ & NCT00733408 \\
\hline \multirow[t]{3}{*}{$\mathrm{ACT}$} & NK cells & $\mathrm{BC}$ & Recruiting & $|/| \mid$ & NCT02843126 \\
\hline & Anti-MUC1 CAR-T cells & TNBC, HCC, NSCLC, PC & Recruiting & $|/| \mid$ & NCT02587689 \\
\hline & NKG2D CAR-T cells & TNBC, CRC, OC, UC, PC, MM & Recruiting & $|/| \mid$ & NCT03018405 \\
\hline \multirow[t]{2}{*}{ Vaccine } & haNK cell & TNBC & Not yet recruiting & $|\mathrm{b} /| \mid$ & NCT03387085 \\
\hline & & & & Ib/II & NCT03175666 \\
\hline \multirow[t]{4}{*}{$A D C$} & IMMU-132 & TNBC & Recruiting & III & NCT02574455 \\
\hline & & & Not yet recruiting & $\|$ & NCT02161679 \\
\hline & CDX-011 & TNBC & Active, not recruiting & $\|$ & NCT01997333 \\
\hline & SGN-LIV1A & TNBC & Recruiting & । & NCT01969643 \\
\hline ADC, PD-1 & SGN-LIV1A, Pembrolizumab & TNBC & Recruiting & $|\mathrm{b} /| \mid$ & NCT03310957 \\
\hline
\end{tabular}

cells. The U.S. FDA approved Bristol-Myers Squibb's anti-CTLA-4 treatment, called ipilimumab, for metastatic melanoma in 2011; ipilimumab showed a durable and potentially curative efficacy in potentiating tumour regression, with a higher complete response rate than in previous reports [44, 45].

High infiltration of Tregs in a tumour is usually associated with poor prognosis. Removal of Foxp $3^{+}$Tregs can evoke and enhance the anti-tumour immune response because they not only suppress aberrant immune responses but also inhibit anti-tumour immune responses [46]. The CTLA-4 antibody mediates antitumour immunity through Akt phosphorylation and the blockade of Foxp $3^{+}$Treg cells in the TME, which allows for potent T-cell expansion [47, 48]. A systematic review demonstrated that TNBC encompasses the highest incidence of TILs (20\%; range, 4-37\%) and the highest levels of Foxp $3^{+}$Tregs cells (70\%; range, 65-76\%) among breast cancer subtypes [49]. The elevated numbers of Foxp $^{+}$Tregs $\left(\sim 66 \%\right.$ of CD $4^{+} \mathrm{T}$ cells $)$ may be therapeutic targets of CTLA-4 blockade antibodies in TNBC treatment [47]. While the disappearance of FoxP3 ${ }^{+}$Tregs is associated with pCR to neoadjuvant chemotherapy; how this could affect the response to anti-CTLA- 4 treatment in TNBC remains controversial, with few investigations involved [50]. Limited preclinical data showed that antiCTLA-4 did not significantly alter tumour growth except when Tregs were depleted [51]. While the anti-CTLA-4 antibodies Ipilimumab and Tremelimumab are currently undergoing clinical trials of TNBC (Table 1), more investigations are warranted to confirm the relationship between Treg infiltration and treatment response in TNBC.

\section{Combination of immune checkpoint inhibitors with targeted treatments in TNBC}

Despite the remarkable benefits from the use of checkpoint inhibitors, clinical trials evaluating the use of combinations of checkpoint inhibitors to improve the response rate are now demonstrating that dual application of immune checkpoints inhibitors (blockade of CTLA-4 and PD-1/PD-L1 pathways) is a promising approach in TNBC. Additionally, combination therapy of checkpoint inhibitors with targeted treatments has shown the ability to increase the efficacy of immunotherapy and to slow down primary tumour outgrowth and metastasis, especially in the neoadjuvant background, and may simultaneously improve the tumour-specific $\mathrm{T}$ 
lymphocyte response, which is observed in multiple syngeneic TNBC models [38].

\section{Dual application of immune checkpoint inhibitors (anti-PD-1 and anti-CTLA-4) in TNBC}

Although a number of trials with PD-1 inhibitors are encouraging for TNBC, only a fraction of treated patients detectably respond to this therapy. PD-1 and CTLA-4 exert their effects through distinct mechanisms [52], and people have gradually realized that simultaneously targeting both pathways may result in a synergistic effect on anti-tumour immunity, and the combination of the blockade of PD-1 and CTLA-4 possess more than twice the efficacy of either alone in melanoma and lung cancer [53-55]. Moreover, the blockade of both PD-1 and CTLA-4 restores $\mathrm{T}$ lymphocyte rejection function in tumours, especially when combined with GVAX vaccination (consisting of GM-CSF-expressing irradiated tumour cells) [56].

However, only few investigations involving $\mathrm{BC}$ were carried out. A combination of these two antibodies over comes tumour immunosuppression and effectively treats TNBC, with a regression of $\sim 80 \%$ of tumours [47], allowing inactivated tumour-specific $\mathrm{T}$ lymphocytes to continue to expand and carry out effector functions, and this shifts the TME from suppressive to inflammatory [54]. Therefore, understanding of pharmacodynamic effects of the combination of these two antibodies in patients will definitely prompt the rational development of immunebased combinations against TNBC. Moreover, dual antiPD-1 and anti-CTLA-4 combined with Cisplatin therapy not only led to an avid cytotoxic, rather than suppressive, immune response, characterized by enhanced DC activation, decreased FOXP3 ${ }^{+}$Tregs and concomitantly increased activation of $\mathrm{CD} 8^{+} \mathrm{CD} 4^{+} \mathrm{T}$ cells $(\mathrm{p}<0.05)$, but also more efficiently curtailed BRCA-1 deficient tumour growth $(\mathrm{p}=0.008)$ [57].

\section{Anti-PD-1/PD-L1 mAbs combined with targeted therapies Anti-PD-1/PD-L1 mAbs with EGFR inhibitors}

As a member of the family of transmembrane receptors, EGFR (epidermal growth factor receptor) promotes cell proliferation and survival via initiating downstream signalling through the PI3K-AKT-mTOR and RAS-MEK pathways [58]. More importantly, EGFR works as a cotranscription factor that is localized in the nucleus and results in cancer progression. Currently, there are two main monoclonal antibodies (mAb) targeting EGFR, cetuximab and panitumumab. Cetuximab is a chimeric IgG1 mAb that blocks the ligand-induced phosphorylation of EGFR through binding to EGFR in cancer cells, with a higher affinity than both EGF and TGF- $\alpha$ [58]. In terms of breast cancer, nuclear EGFR expression is associated with resistance to gefitinib, an oral tyrosine kinase inhibitor (TKI), in vitro [59]. Moreover, nuclear EGFR expression also correlates with a more aggressive clinical behaviour in breast cancer [60]. EGFR expression is predominant in $89.5 \%$ of TNBC and can be transferred from TNBC cells to immune cells, leading to a decreased level of EGFR on TNBC cells, and its expression on immune cells correlates with a high tumour grade in TNBC patients $(p=0.02)[61,62]$. This indicates that EGFR can be transferred via trogocytosis from one cell to another at the time of contact and may alter the function of immune cells [63]. EGFR down-regulation also induces the reduction of PD-L1 expression on cancer cells [64], which could improve the efficacy of these inhibitors in TNBC. Further investigation is warranted to elucidate the mechanism of modulation of EGFR by immune cell contact to TNBC cells and its interaction with the reduction of PD-L1 expression, which may provide novel aspects for immunotherapy for TNBC.

Moreover, EGFR signalling may promote tumour growth and enhance immune escape by stimulating aerobic glycolysis in TNBC cells and producing lactate, which inhibits $\mathrm{T}$ cell activity [65]. In the past two decades, cetuximab has shown marked anti-tumour efficacy, including increasing the anti-tumour effects of doxorubicin [66], prolonging the PFS of TNBC patients in combination with cisplatin [67] and increasing the response rate for TNBC in combination with irinotecan [68]. Panitumumab is a fully humanized IgG G2 mAb, which is directed to EGFR to competitively inhibit EGFR binding, and has also been studied in TNBC [58]. Combined with chemotherapy, panitumumab also raises the $\mathrm{pCR}$ rate in TNBC patients [69]. In addition, dual EGFR inhibition, either by a combination of noncompetitive EGFR mAbs or a combination of an EGFR mAb and an EGFR tyrosine kinase inhibitor, might exert an improved antitumour effect in TNBC [70, 71]. Currently, a number of clinical trials have been carried out treating TNBC with anti-EGFR mAbs, and encouraging results will be yielded soon.

Despite the encouraging data on anti-PD-1/PD-L1, the efficacy of PD-1/PD-L1 inhibitors in patients with EGFR-activating mutations remains unclear. Preclinical investigations involving NSCLC and head and neck cancer revealed the immune modulatory effect of the EGFR signalling pathway, including repression of MHC I and MHC II [72], upregulation of PD-L1 expression (through the AKT/mTOR pathway, AKT-STAT3 pathway and ERK1/2 pathway) [73, 74], increasing the number and activity of immunosuppressive Tregs (through the EGFR/ GSK-3b/Foxp3 axis) [75], and inhibiting the activity of CTLs [65]. Therefore, inhibiting EGFR by either mAbs 
or EGFR-TKIs could decrease the expression of PD-L1 in tumours.

However, the PD1/PD-L1 pathway might accounted for EGFR-TKIs resistance [76]. Delayed tumour growth and increased survival have been demonstrated in preclinical EGFR mutant lung cancer models treated with anti-PD-1 mAbs [77]. Together, combination of anti-PD-L1 mAbs with anti-EGFR mAbs or EGFR inhibitors will probably exert a synergetic effect. To better apply this combination to treatment of TNBC, further investigations are warranted to demonstrate the exact interaction between the PD-1/PD-L1 and EGFR pathways and the efficacy of this combination in TNBC.

\section{Anti-PD-1/PD-L1 with VEGF inhibitors}

Vascular endothelial growth factor A (VEGF-A) is released by tumour cells and is associated with tumour progression, angiogenesis and invasion in TNBC and other malignancies [78]. In a TNBC patient cohort, Su, Jung-Chen profiled VEGF-A levels and found associations with distant metastasis-free survival (DMFS) and disease-free survival (DFS), further demonstrating that high VEGF-A levels correlate with the risk of developing metastatic disease in TNBC [79]. Bevacizumab (BM) is a recombinant humanized $\mathrm{mAb}$ that blocks angiogenesis by targeting VEGF-A and was first approved for medical use in the United States in July 2004 [80]. Some maintain that the reduced number and function of tumour vessels induced by an antiangiogenic treatment might impact the intratumoural delivery of concurrently applied chemotherapy. Still, the efficacy of additional BM remains controversial across the world. Although the FDA ruled to withdraw its indication for advanced breast cancer in 2011, BM remains in application in other countries, including Australia. The addition of $\mathrm{BM}$ has been shown to improve the overall response rate (ORS) and PFS in patients with metastatic TNBC [81-83]. Although the randomized phase III BEATRICE trial showed no significant benefit from BM therapy for early TNBC [84], a trend towards an improved OS was observed in the triple-negative subgroup who received BM. Thus, BM not only helps to overcome adaptive resistance but also improves tumour perfusion to maintain intratumoural drug delivery when combined with a rational and complementary chemotherapy partner $[85,86]$. The NSABPB-40 trials showed a significantly improved OS with BM [87], and the GINECO A-TaXel Phase 2 Study also showed high activity and manageable safety for the combination of paclitaxel, capecitabine and BM in TNBC [88].

As mentioned above, VEGF has an effect in immune regulation by suppressing antitumour immune responses [89]. VEGF-A produced in the TME enhances expression of PD-1 and other immune checkpoint molecules, and high levels of VEGF-A might be involved in resistance to PD-1 blockades, which could be reverted by targeting the VEGF-A/VEGFR pathway [90]. Blocking the VEGF pathway could also potentiate anti-PD-L1 mAb (atezolizumab) therapy and improve antigen-specific T-cell migration [91, 92]. A phase I study evaluating atezolizumab in combination with BM showed an overall response rate of $40 \%$ in metastatic renal cell carcinoma [92] and was well-tolerated in these patients without synergistic toxicity, which is important because both PD-1 and VEGF blockades were thought to cause unique adverse events, such as autoimmune diseases in some patients [91].

Bevacizumab has been shown to improve the ORS and PFS of patients with metastatic TNBC and improve intratumoural drug perfusion for combination chemotherapy (reviewed above), which shows that combining two agents may be a promising strategy. The similar synergistic anti-tumour effect in vivo can also be induced successfully by combining PD-1/PD-L1 and VEGF-A/ VEGFR blockade [93], although few cases of patients with TNBC who had a significant response to combinational treatment of anti-VEGF with immune check-point blockade have been reported so far. In view of these, targeting VEGF-A/VEGFR could synergize with anti-PD-1/ PD-L1 treatment and might be a good candidate for TNBC treatment.

\section{Anti-PD-1/PD-L1 with PARP inhibitors}

Similar to BRCA1-mutated tumours, $25 \%$ of sporadic breast cancers are deficient in DNA-repair, mainly in homologous recombination (HR) when double stranded DNA breakage (DSB) occurs [94]. PARP [Poly (ADPribose) polymerase] is a nuclear enzyme that participates in the repair of DNA single-strand breaks (SSBs) via the base excision repair pathway, and it is highly expressed in more than $90 \%$ of TNBC [95]. Inhibition of PARP results in accumulation of SSBs, which can lead to the formation of irreparable toxic DSBs in BRCA1/2 defective cells [96]. PARP inhibitors are promising agents for the treatment of BL-1 (basal-like 1) TNBC, which features an enriched cell cycle, elevated DNA damage response (ATR/BRCA), proliferation pathway, and cell-cycle checkpoint loss pathways [97]. PARP inhibitors serve as a group of novel oral anticancer drugs that are highly active in TNBC with selected mutations or epigenetic silencing of genes involved in the DNA damage response (DDR), including BRCA1 and BRCA2 [98]. However, PARP inhibitors can upregulate PD-L1 expression and enhance cancerassociated immunosuppression. Thus, anti-PD-1/PD-L1 mAbs may exert a supplementary and increased antitumour effect in combination with a PARP inhibitor [99]. 
To further confirm the efficacy of this combination, a few clinical trials have been carried out (Table 1).

\section{Anti-PD-1/PD-L1 with anti-MMP-14 antibodies for potential application}

The matrix metalloproteinase (MMP) family mediates ECM degradation and promotes cancer metastasis [100]. MMPs are localized to invadopodia, which are filamentous actin (F-actin)-rich cellular protrusions that degrade ECM, and MMP-14, a cell surface receptor that degrades collagen, is required for invadopodia formation, which activates secreted MMPs to promote cancer metastasis $[101,102]$. Targeting the early steps in metastasis, such as ECM degradation and invasion in cancer cells, may improve outcomes in TNBC [103]. The enhanced expression of MMP-14 probably leads to concordantly enhanced metastasis in cancer models and is associated with a comparatively poor prognosis in human breast cancer [104]. Several selective MMP-14 antibodies have been exploited. DX-2400, a potent and highly selective human antibody inhibitor of MMP-14 activity, significantly decreases MMP-14 activity, decreases immunosuppressive TGF- $\beta$, polarizes macrophages to an anti-tumour phenotype, and increases iNOS, leading to impaired primary tumour growth and an improved response to radiation therapy [105]. Moreover, some specific $\mathrm{scFv}$ antibodies bind outside the catalytic cleft of MMP-14 and impactfully prevent its proteolytic functions at the surface of cells [106]. Fab R2C7 is another inhibitory Fab with an excellent selectivity for MMP-14 [107]. Fab 3369 inhibits MMP-14-mediated ECM degradation and MDA-MB-231 cell invasion. Through an analysis of lung tissue sections from mice using a human TNBC xenograft model randomized between control IgG and IgG 3369 treatment groups, the MMP-14 inhibitory antibody 3369 was found to limit MDA-MB-231 tumour xenograft growth and metastasis [108]. More interestingly, Binbing Ling also demonstrated the potential of MMP-14 blockade to disrupt the immunosuppressive TME in metastatic breast cancers, while a number of immune regulatory genes were altered with MMP14 blockade [108]. However, at this point, there have been no reports or clinical trials on targeting MMP-14 together with anti-PD-1/PD-L1 treatment; more potential therapies can be applied in patients with TNBC in the future.

Currently, a number of clinical trials involving antiimmune checkpoint inhibitors, cytokines and their antibodies (anti-PD-1: Pembrolizumab, JS001, PDR001, Nivolumab; anti-PD-L1: Atezolizumab, Durvalumab; anti-CTLA-4: Ipilimumab, Tremelimumab; anti-EGFR mAb: Cetuximab, Panitumumab; anti-VEGF-A mAb: Bevacizumab; anti-MMP-14 antibody: Fab 3369, Fab
R2C7, DX 2400) have been carried out to treat TNBC (Fig. 1). These agents might have a notably broad range of action with consequent problems influencing the future applications in the treatment of TNBC. Therefore, more research on specified immune checkpoint inhibitors and monoclonal antibodies for TNBC is urgently required.

\section{Adoptive cell therapy (ACT)}

Adoptive cell therapy is a promising and likely potent approach to inducing anti-tumour immune responses via the isolation of highly active and tumour-specific lymphocytes, including TILs, cytotoxic $\mathrm{T}$ lymphocytes (CTLs), Th cells, NK and DC cells, large-scale ex vivo expansion and the activation of these lymphocytes for autologous therapy $[109,110]$. As the ultimate effector cells, CTLs express a unique T-cell-antigen receptor (TCR) that confers specificity for the particular target antigen. The productive engagement of TCR/MHC/antigen complexes on the target-cell surface triggers the CTL's effector functions and induces the destruction of the target cell through the release of inflammatory cytokines, including tumour-necrosis factor- $\alpha$ (TNF$\alpha)$, IFN- $\gamma$, FAS ligand (FASL), TNF-related apoptosisinducing ligand (TRAIL) and cytotoxic degranulation [109]. NK cells play a critical role in cancer immunosurveillance. Therapies utilizing NK cells have shown great promise due to advances in NK cell expansion protocols [111, 112], which are classified as follows: (1) harnessing endogenous responses by NK stimulants or targeting agents and (2) using exogenous NK cells via haematopoietic stem cell transplant (HSCT) or ACT [113]. Clinical studies show that NK cells from BC patients can be expanded and have a high cytotoxic ability to kill breast cancer cells $[113,114]$. Until now, ACT has been successfully used for the treatment of patients with metastatic melanoma, leukaemia, and neuroblastoma [115, 116]. Therefore, with host immune environment manipulation, including the pre-administration host immunosuppression and concurrent cytokine administration, with the transferred cells, more novel adoptive cell therapies can be applied in patients with TNBC in the future.

\section{Chimeric antigen receptors T-cell-based therapy}

Having underdone almost 30 years of evolution since the first generation of chimeric antigen receptors (CARs) was developed in 1989 by Gross G [117], this technology is still in its early stage of exploitation and development and facing nonignorable challenges, namely, the inability to control the rate of cytokine release and tumour lysis. In 2010, Rosenberg published chimeric antigen receptor therapy (CAR therapy)-a personalized treatment involving genetically modifying a patient's $\mathrm{T}$ cells to make them target tumour cells [118]. Currently, multiple 


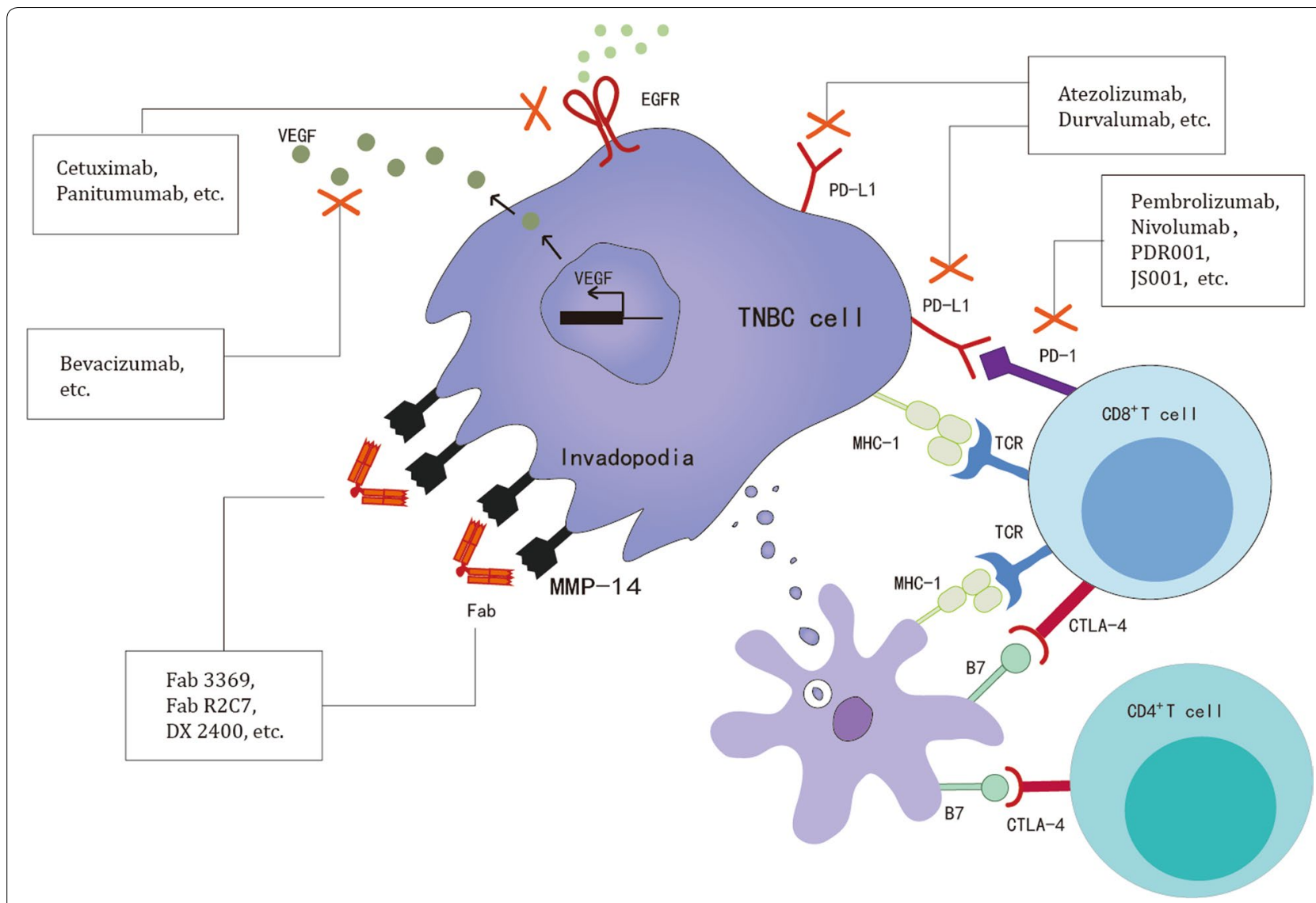

Fig. 1 Current and potential future immune-related drug targets in TNBC, including immune checkpoint inhibitors, cytokines, and their antibodies

organizations are developing CARs against a host of targets, from epidermal growth factor receptor variant III (EGFRvIII) and mesothelin to CD19, CD20, CD30, CD33, and CD138 [119]. To date, ACT therapy has gained much attention in the past decade, especially CAR-T cell therapy, which grafts an arbitrary specificity onto an immune effector $\mathrm{T}$ cell. CARs are fusion receptors that are composed of an antibody-derived single-chain variable fragment $(\mathrm{scFv})$ coupled via hinge and transmembrane elements to a $\mathrm{T}$ cell signalling and co-stimulatory domain. Recently, the novel CAR-T was engineered to express interleukin-7 (IL-7) and CCL19 [120].

A few agents have been developed and applied to CAR-T cells for TNBC treatment. Several CAR-T based ACTs were used in current clinical trials, such as ROR1 ${ }^{+}$CAR-T cells, anti-MUC1 CAR-T cells and NKG2D CAR-T cells. More candidates are in development. A patented antibody (TAB 004) specifically recognizes a tumour-associated form of MUC1 (tMUC1) in $>90 \%$ of human TNBC, and the antigenic isoform recognized by TAB 004 is completely hidden in normal epithelia, which makes it extremely safe for the development of CAR-T cells [121]. Mesothelin might have promise as a unique tumour associated antigen for TNBC; it has been screened in 99 primary breast cancers (it was overexpressed in 67\% TNBC but $<5 \%$ $\mathrm{ER}(+)$ or Her2-neu ${ }^{+}$type, and was undetectable in non-neoplastic mammary epithelium) [122]. TEM8 CAR-T cells were also recently postulated as a promising CAR-T-cell-based therapy, in which the TEM8 CAR $\mathrm{T}$ cells induce the regression of both established, localized patient-derived xenograft tumours (PDX) and lung metastatic TNBC cell line-derived xenograft tumours, by both killing the TEM $8^{+}$TNBC tumour cells and targeting the tumour endothelium to block tumour neovascularization [123]. Moreover, there is an increasing number of potential targets that are comparably highly expressed in TNBCs, such as FR $\alpha$ and brachyury, that have been developed [124, 125], which may provide implications for clinical tumour antigen screening for CAR-T cell-based therapies.

\section{T cell receptors (TCRs) - engineered $T$ cells}

TCR-engineered $\mathrm{T}$ cells are $\mathrm{CD} 8^{+} \mathrm{T}$ cells efficiently engineered to express TCRs recognizing intracellular 
antigens processed by major histocompatibility (MHC) proteins, which can target and kill cancer cells expressing appropriate antigens [126]. Investigations of TCR-engineered $T$ cells began over two decades ago, with a number of preclinical studies showing their ability to mediate tumour lysis and eradication. The large amount of attention has recently led to the increased development of this ACT, which has shown encouraging outcomes in studies of TCR-engineered $\mathrm{T}$ cells directed against NY-ESO-1, MAGE and GP100, with significant clinical successes in patients with colorectal carcinoma, synovial sarcoma, metastatic melanoma and multiple myeloma [126, 127]. Recently, placenta-specific 1 (PLAC1)-specific HLAA0201-restricted TCR-engineered $\mathrm{CD}^{+} \mathrm{T}$ cells were developed to kill breast cancer cells by producing IFN- $\gamma$ and TNF- $\alpha$ [128]. However, more widespread utilization of TCR-engineered T cells in solid tumours such as TNBC calls for the enhancement of long-term survival and function of the cells, as well as closed culture procedures capable of expanding $\mathrm{T}$ cells to sufficient numbers for clinical application. Fortunately, modular systems and semi-automated devices have been developed and used in large-scale manufacturing [129]. Moreover, CRISPR/ Cas9 technology can improve the function and sensitivity of TCR-engineered $\mathrm{T}$ cells to antigens by redirecting primary $\mathrm{T}$ cells with a pan-cancer reactive $\gamma \delta \mathrm{TCR}$ in combination with endogenous TCR- $\beta$ knockout [130]. Of note, TCR-engineered T cells expressing a high level of PD-1 could reduce their functional activity; the efficacy of these cells may be augmented when used in combination with anti-PD-1 mAbs [131, 132].

\section{Tumour-infiltrating lymphocytes}

Tumour-infiltrating lymphocytes are white blood cells that have left the bloodstream and migrated into a tumour; they are composed of a mix of different types of mononuclear immune cells ( $\mathrm{T}$ cells, B cells, NK cells, and macrophages) in variable proportions, of which $\mathrm{T}$ cells are dominant [133]. Known as indicators of immunogenicity, TILs are not only remarkably prognostic but are also significantly predictive for tumours in cutaneous melanoma [134], colorectal cancer [135, 136], urothelial carcinoma [137] and breast cancer [133]. TILs also show a robust prognostic and predictive value in TNBC, indicating the immune status of the tumour and determining the efficacy of conventional chemotherapy $[138,139]$. However, paradoxical results have emerged in several studies, suggesting that some $\mathrm{CD} 8^{+} \mathrm{T}$ cell-infiltrated tumours show poor outcome. Some efficient $\mathrm{CD}^{+} \mathrm{T}$ cell invasion and infiltration in the tumour is correlated with good outcome, while some patients show poor outcome due to the accumulation of $\mathrm{CD}^{+} \mathrm{T}$ cells in the tumour-associated stroma, with poor infiltration in the tumour epithelium [140]. A high amount of TILs suggests an immune status of a tumour near an equilibrium between then cancer and immune equilibrium in TNBC [141]. Surgical resection of the primary tumour has also been found to tilt the balance towards the immune system and, therefore, result in a better prognosis of high TILs in TNBC [141]. Low TILs correlate with a greater clonal heterogeneity and mutation load in TNBC, which may consequently lead to tumour escape from immune surveillance. It is not TILs alone, however, but also the balance between distinct immune components in the TME that impacts the outcome of patients with TNBC. TNBC patients experiencing tumour recurrence show a decreased content of TILs and an increased number of $\mathrm{CD}_{163}{ }^{+}$tumour-associated macrophages (TAMs) compared with those without recurrence [142]. High levels of tumour infiltrating $\mathrm{CD} 8^{+} \mathrm{T}$ cells may reflect an improved prognosis with chemotherapy sensitivity, and TAMs correlate with a poor outcome in TNBC patients [138]. On the other hand, the heterogeneity of the $\mathrm{CD} 8^{+} \mathrm{T}$ cell distribution also crucially composes the newly identified distinct immune microenvironment of TNBC [140].

Despite the tremendous progress made regarding $\mathrm{ACT}$, the potential of ACT therapy is facing inevitable challenges, such as expanding specific cells, including $\mathrm{CD}^{+} \mathrm{T}$ cells. Increasing efforts have been made to expand $\mathrm{CD} 8^{+} \mathrm{T}$ cells, NK cells and DCs, which will probably be utilized in autologous ACT for TNBC. Expanded NK cells from PBMCs isolated from breast cancer patients survive in vivo and prevent the establishment and growth of TNBC cells in a xenograft mouse model [114]. Cytokine-induced killer (CIK) cells have also emerged as a potential ACT option, for their impressive efficacy in improving DFS and OS in TNBC patients [143]. Further improvements in ACT therapy call for a deeper understanding of the immunological processes, the ability of lymphocytes to persist in vivo and to travel to tumours, unexpected toxicities to normal tissue, and the mechanisms of ACT augmentation by previous host immunosuppression.

\section{Cancer vaccine}

Sipuleucel-T, a personalized treatment working by programming each patient's immune system, is a therapeutic vaccine for prostate cancer approved by the FDA in April 2010, showing an ability to improve overall survival in patients with castrate-resistant prostate cancer. The MAGE-3 protein-based vaccine is also undergoing phase III clinical trial testing in patients with melanoma and NSCLC [144]. To date, a tremendous number of cancer vaccines, from peptide vaccines such as PPV, to DNA vaccines such as the hDR5 DNA vaccine, and from cytokine vaccines such as combined GM-CSF to 
Lymphocyte vaccines such as a DC-related vaccine, are carving the way for TNBC treatment.

\section{Cancer-testis antigens (CTA) as a vaccine target}

Cancer-testis antigens are a heterogeneous group of TAAs displaying the ideal characteristics of promising immunotherapeutic targets [145]. Several CTAs are specifically expressed in TNBC, including SP17, NY-ESO-1 and MAGE group [146]. Sperm Protein 17 (SP17) was originally identified in the flagellum of rabbit spermatozoa [147] and is localized in the human fibrous sheath (FS) of sperm flagellum during different phases of spermatozoa maturation [148]. SP17-specific cytotoxic T lymphocytes were successfully generated from normal donors [149]. SP17 is aberrantly expressed in ovarian cancers [150], oesophageal cancer [151], nervous system tumours [152], endometrial and cervical cancers [153], NSCLC [154], and myeloma [155], and is associated with the migratory and motility capacity of tumour cells, indicating a link between the gene expression patterns in germinal and tumour cells of different histological origins [156] and is suggested as a promising target for immunotherapy. SP17 is expressed in both breast cancer cell lines and primary breast tumours and, importantly, in the TNBC subtype. Moreover, the detected specific anti-SP17 antibodies in patient sera was used to generate SP17-specific, HLA class I-restricted, cytotoxic $\mathrm{T}$ lymphocytes capable of efficiently killing breast cancer cells [145]. Early clinical data and assays in some respects support the rationale for further investigations of SP17 for tumour vaccines [157]. NY-ESO-1 expression is an independent good prognostic factor $(\mathrm{p}=0.046)$ in TNBC and leads to a high humoural immune response associated with higher TILs $[158,159]$. Therefore, the detection of NY-ESO-1 expression in TNBC might be useful for selecting patients who may benefit from cancer vaccination therapy.

\section{Personalized peptide vaccination (PPV)}

A novel regimen of personalized peptide vaccination, which was developed by Itoh $\mathrm{K}$, has been used in a phase II trial [160], and selected vaccine antigens from a pool of 31 peptides showed boosted immune activation and a noted clinical response [160]. An intramuscular vaccination with TNF-related apoptosis-inducing ligand receptor TRAIL R2 or death receptor 5 (DR5) DNA, as a novel promising vaccine target, not only elicits proapoptotic antibodies and IFN- $\gamma$-producing $\mathrm{T}$ cells $(\mathrm{p}<0.001)$ but also inhibits TNBC SUM159 growth by hDR5 immune serum $(\mathrm{p}=0.02)$ [161]. GM-CSF, combined with breast cancer stem cell- associated antigens and cytosine-phosphorothioate-guanine oligodeoxynucleotides (CpG-ODNs) in spontaneous breast cancer
TA2 mice, is efficacious not only in suppressing tumour growth $(\mathrm{p}=0.035)$ but also in activating and accumulating $\mathrm{CD}^{+} \mathrm{CD}^{+} \mathrm{T}$ cells to kill tumour cells $(\mathrm{p}=0.001)$ $(\mathrm{P}<0.05)[162]$.

\section{Antigen-presenting cell (APC) and DC-based tumour vaccination}

APC and DC-based tumour vaccination have been deeply investigated and met with noted success in several malignancies, including TNBC. O'Shaughnessy successfully gave 10 TNBC patients autologous monocyte-derived DC vaccinations intratumourally and subcutaneously during preop chemotherapy, which turned out to be safe [163]. Day-3 DCs fused with whole apoptotic breast cancer MDA-MB-231 cells could elicit effective specific anti-tumour $\mathrm{T}$ cell responses and might be developed as a prospective vaccine for BC immunotherapy [164]. Cocultured DCs isolated from healthy donors and transduced by Runx2 with T cells also induce CTL and kill TNBC cells [165].

In summary, TNBC is regarded as the prime subtype of breast cancers and is amenable to immune checkpoint inhibition. There are currently a number of selective inhibitors, such as immune checkpoint inhibitors, cytokines, and their antibodies, as mentioned above, and adoptive cell therapy and cancer vaccines have also gained much attention in the past decade. Recently, some of these targets have entered into initiated clinical trials of immunotherapeutic interventions of TNBC (Table 1), which may have a notably broad range of action, with consequent problems influencing the future applications in the treatment of TNBC.

\section{Efficacy of immunotherapy and future perspectives in TNBC}

Synergistic effect of immunotherapy and chemotherapy Increasing number of studies suggest that the chemotherapeutic agents such as anthracyclines, Cisplatin and Carboplatin exert their anti-tumour activity not only by directing cytotoxic effects but also by changing the TIL distribution. Chemotherapy with anthracyclines also requires priming of IFN- $\gamma$ producing $\mathrm{CD}^{+} \mathrm{T}$ cells in mice [166].

There are several studies involving combinations among immune checkpoint blockade, anti-EGFR antibody, ACT, Cisplatin, Carboplatin, Cyclophosphamide, Doxisome, and Paclitaxel, and the efficacy of chemotherapy requires immune cells, such as $\mathrm{CD}^{+}$cells, and cytokines, such as IFN- $\gamma$, genes, such as CD $8 \alpha / \beta$, IFN- $\gamma$, IL- $1 \beta$ and IL-17, and the IL- $1 \beta /$ IL-1R signalling pathway [167]. There are several mechanistic reasons that this combination works. First, chemotherapy alters the immune gene signatures in TNBC and several metabolic 
pathways are also upregulated in response to cytotoxic therapy [168]. Second, both chemotherapy and checkpoint antibodies induce positive changes in the TME and improve the outcome of TNBC patients. High levels of IFN- $\gamma$, TIL counts, and the corresponding enhanced immune response are associated with better clinical responses to chemotherapy and a high proportion of $\mathrm{pCR}$ $[11,57,167,169]$. Although some chemotherapies may harm lymphocytes, such as $\mathrm{CD} 4^{+}, \mathrm{CD} 20^{+}$and $\mathrm{CD} 68^{+}$ cells, they decrease immunosuppressive Foxp $3^{+}$Tregs, maintain or even increase $\mathrm{CD} 8^{+}$effectors, and invert the CD4/CD8 ratio [50, 170]. Finally, chemotherapy-induced cells release ATP to activate the NLRP3 inflammasome in DCs by releasing IL-1 $\beta$ [166]. Therefore, these changeable gene signatures in TNBC and the immune cells and cytokines of TME are maybe the reason why chemotherapy improves immunotherapy; although, it could possibly harm lymphocytes.

On the other hand, TNBC responses to anti-PD-1 or anti-PD-L1 are modest $(<20 \%)$ and a high expression of PD-L1 is associated with an enhanced response, which demonstrates that immune checkpoint blockade in the neoadjuvant setting enhances the effects of the conventional neoadjuvant chemotherapy alone [169]. Treatment with anti-PD-1 during DC maturation enhances DC survival [171]. The synergistic therapeutic activity of Doxisome (liposomal encapsulated formulation of Doxorubicin) with anti-PD1 is due to increased DCs infiltration in the TME, which internalizes tumour antigens, induces $\mathrm{T}$ cell anti-tumour immune responses, and increases the therapy response in TNBC [172]. Chemotherapies, containing anti-EGFR/VEGF mAbs, also show significantly positive outcomes $[68,87,88]$. A small sample size trial shows that cyclophosphamide, thiotepa and carboplatin, as first-line regimens, combined with DC-CIK immunotherapy and followed by oral low dosage cyclophosphamide, as maintenance therapy, were effective and safe for metastatic TNBC exposure compared to the previously used anthracyclines and taxanebased adjuvant chemotherapy [173]. All these studies demonstrated that the association between the immune response and the clinical outcomes of TNBC probably correlate with the role of the immune cells in the administration of cytotoxic chemotherapy.

\section{Antibody-drug conjugates (ADC)}

Antibody-drug conjugates are a burgeoning new treatment modality that utilizes monoclonal antibodies that recognize TAAs/TSAs and preferably internalizes when bound to the tumour cells to deliver highly potent cytotoxic agents [174]. There are at least 100 clinical trials involving ADCs in different types of cancers, including melanoma, gastrointestinal cancer, pancreatic cancer, colorectal cancer, ovarian cancer, cervical cancer, and endometrial cancer. (https://clinicaltrials.gov/ct2/resul ts? cond $=$ antib ody \pm drug \pm conjugate $\&$ term $=\&$ cntry $=\&$ state $=\&$ city $=\&$ dist $=$ ), and three ADCs $($ SGN-LIV1A, glembatumumab vedotin (CDX-011, CR011-vcMMAE) and Sacituzumab Govitecan (MMU-132, hRS7-SN-38) are carried out to treat TNBC among these clinical trials.

The zinc transporter LIV-1 (SLC39A6) is overexpressed in TNBC and is maintained after hormonal therapy in primary and metastatic sites. SGN-LIV1A is an anti-LIV-1 antibody linked to a potent microtube disrupting agent monomethyl auristatin E (MMAE) via a cleavable dipeptide linker and displays specific cytotoxicity both in vitro and in vivo against LIV-1 expressing cancer cells by internalizing and trafficking to the lysosome [175]. IMMU-132 is made from a humanized antiTrop-2 (expressed in TNBC) mAb (hRS7) conjugated with SN-38 (the active metabolite of irinotecan) and is well tolerated and induces early and durable responses in heavily pretreated patients with metastatic TNBC, which mediates early pro-apoptosis signalling events (p53 and p21 WAF1/Cip1) and leads to the cleavage of PARP [176, 177]. A combination of IMMU-132 plus PARP inhibitors, such as olaparib or talazoparib, produces significantly improved anti-tumour effects and delays tumour progression compared with monotherapy in mice bearing BRCA1/2-mutated TNBC [178]. Glycoprotein NMB (gpNMB) is a novel type I transmembrane protein that is overexpressed in most breast cancers and promotes metastases by mediating intercellular adhesion, promoting tissue repair, regulating cell growth and differentiation, and down-modulating anti-tumour T-cell responses. CDX-011 is composed of an antigpNMB mAb and MMAE and has a clinically acceptable safety profile in its first study in breast cancer, showing 12 weeks of PFS in $60 \%$ of TNBC patients treated with CDX-011 [179]. The EMERGE trial also confirmed its enhanced activity in patients with gpNMB-overexpressing TNBC [180]. More pivotal clinical trials concerning these promising ADCs are currently underway and more new ADCs, such as protein tyrosine kinase 7 (PTK7)targeted ADC, and novel potential candidates for ADC, such as STM108, are in development $[37,181]$.

\section{Exosomes as potential multifunctional therapeutic agents in TNBC}

Exosomes, known as small 30-100 nm sized extracellular vesicles, are present in many and perhaps all eukaryotic fluids regardless of whether they are normal or malignant, and are particles that encapsulate contents, such as microRNAs. Exosome messaging contributes to TME interactions, including immune suppression and immune escape, invasive growth, adhesion, angiogenesis, 
radiation resistance, chemo-resistance and genetic intercellular exchange, and can manipulate tumour progression and metastatic cascade [182, 183]. Exosomes were recently reported to play dramatically positive roles in the clinic as targets, biomarkers or even therapeutic agents. Exosomes can be isolated from the blood of patients with various malignancies through various methods, including chemical binding, immunoaffinity capture and differential ultracentrifugation and serve as biomarkers for diagnosis and the monitoring of tumour progression [184]. The innovation of cancer exome-based diagnostic routines would potentiate a route towards the development of personalized immunotherapies [144].

Finally, there is possibility of developing exosomes as therapeutic agents for TNBC. Moreover, some TNBC cells possessing exosome-mediated apoptosis-inducing activity have been investigated [185]. Exosomes that are released from either normal cells or breast cancer cells can either locally or systemically effect neighbouring cells, travelling through the blood and/or lymphoid nodes from other tissues, which is probably regulated by extracellular exosomes [186, 187]. Antigens may increase immune stimulatory capacities when they are carried by exosomes, which could optimize the application of CAR-T therapy and will improve the engineered exosomes, which are emerging as novel vehicles for cancer vaccine development by APC technology. Exosome-based vaccines and exosome pre-loaded miRNAs/ siRNAs/toxic drugs will be therapeutic options for TNBC [188, 189] (Fig. 2). Although exosome-secretion could eliminate some cytotoxic drugs such as doxorubicin and cisplatin, modified exosomes may serve as a novel drug delivery system offering the transportation of anti-cancer drugs with a lower immunogenicity and toxicity [190, 191]. Therefore, the mechanism of this interaction and whether engineered exosomes could be used to inhibit TNBC progression requires further elucidation.

\section{Conclusions}

Overall, it is evident from these studies that immunotherapy is emerging as a novel promising option for TNBC, and there is the possibility of developing exosomes as potential multifunctional therapeutic agents for TNBC. In the future, modern therapeutics needs hold a huge guarantee for the development of affordable, novel and safe antibodies, antibody-drug conjugates, adoptive cell therapies, and cancer vaccines. We expect that exosomes from the tumour microenvironment are likely to become the most effective vaccines for TNBC. With the promising outcomes of immunotherapies, several immunotherapies are being evaluated in phase III trials, which means there would be more therapeutic choices, other than chemotherapy, for TNBC. Immunotherapeutic interventions in TNBC possibly exert a noteworthy effect based on the ongoing clinical trials in the neoadjuvant setting, adjuvant setting and metastatic setting. The synergistic effects and safety concerns of immunotherapy and chemotherapy need be addressed. As it moves towards phase III trials in this field, with a growing interest from pharmaceutical agencies, the final treatment pattern of Triple Negative Breast Cancer will be determined by these ongoing clinical trials, which will lead to a more refined

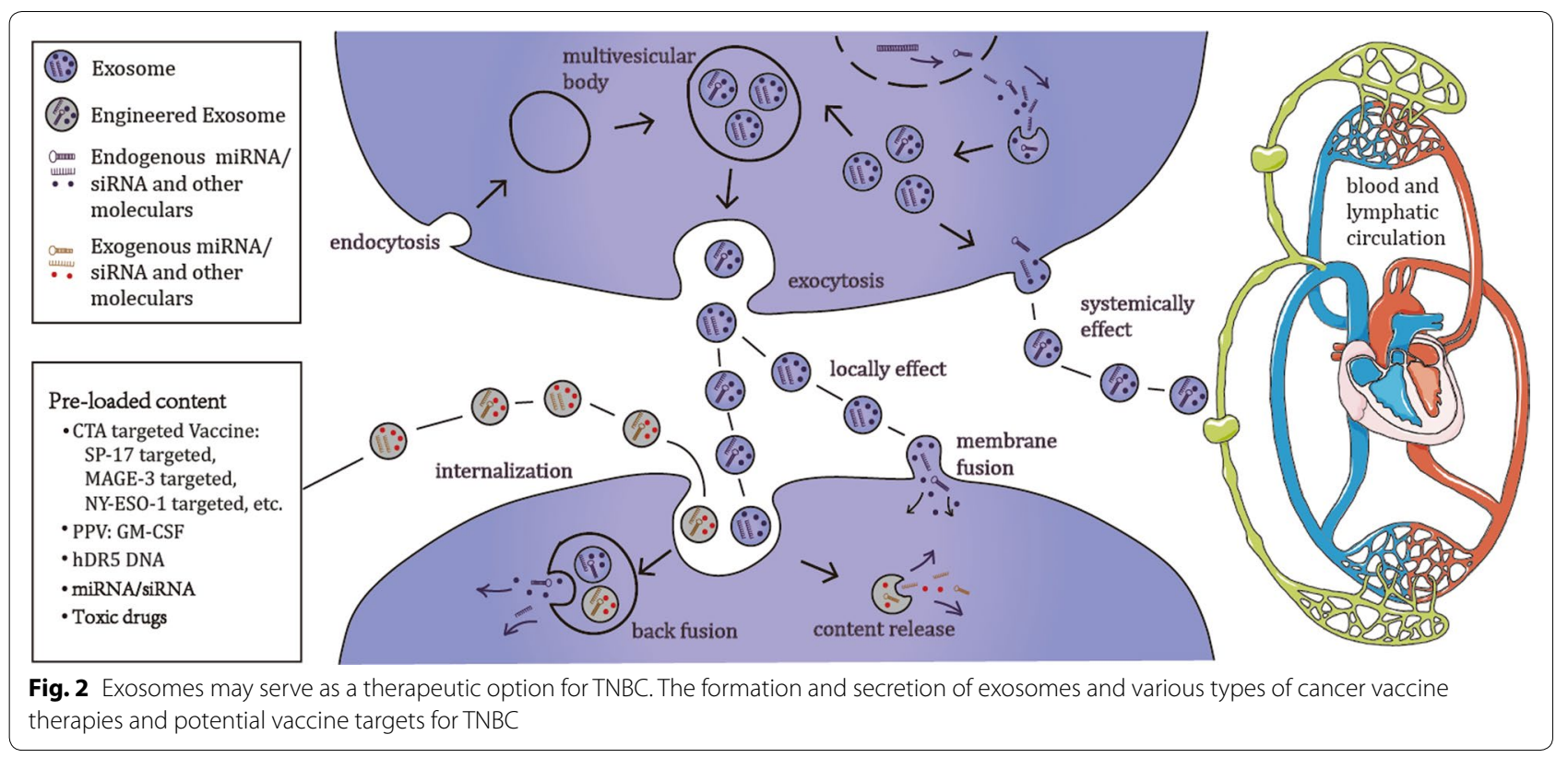


immunotherapy. However, in-depth scientific investigations are required to completely determine the safety and effectiveness of these immunotherapies and open new avenues for the better management of patients with TNBC.

\section{Abbreviations}

AC: doxorubicin/cyclophosphamide; ADC: antibody-drug conjugates; APC: antigen-presenting cell; AT: docetaxel/cyclophosphamide; BC: breast cancer; BM: bevacizumab; CAR: chimeric antigen receptors; CDX-011: glembatumumab vedotin; CIK cell: cytokine-induced killer; CpG-ODNs: cytosinephosphorothioate-guanine oligodeoxynucleotides; CRC: colorectal cancer; CRPC: castrate-resistant prostate cancer; CTA: cancer testis antigen; CTLA-4 cytotoxic T-lymphocyte-associated protein 4; CTLS: cytotoxic T lymphocytes; DC: dendritic cell; DFS: disease-free survival; EGFRvIll: epidermal growth factor receptor variant III; ERs: oestrogen receptors; GEJ: gastric/gastro-oesophageal junction; GM-CSF: granulocyte-macrophage colony-stimulating factor; gpNMB: glycoprotein NMB; haNK: high-affinity Natural Killer; HCC: Hepatocellular Carcinoma; HER2: human epidermal growth factor receptor 2; HNC: head and neck cancer; IFN-Y: interferon gamma; IMMU-132: Sacituzumab Govitecan; IL-7: interleukin-7; mAb: monoclonal antibodies; MM: multiple myeloma; MMAE: monomethyl auristatin E; MMP: matrix metalloproteinase; MSLN: mesothelin; NK cell: natural killer cell; NSCLC: non-small cell lung cancer; OC: ovarian cancer; PBMC: peripheral blood mononuclear cells; PC: prostate cancer; PD-1: programmed cell death protein 1; PD-L1: programmed deathligand 1; PDAC: pancreatic ductal adenocarcinoma; PPV: personalized peptide vaccination; PRs: progesterone receptors; PTK7: protein tyrosine kinase 7; RCC : renal cell carcinoma; $\mathrm{ROR}^{+}$: receptor tyrosine kinase-like orphan receptor 1 positive; SCCHN: squamous cell carcinoma of the head and neck; SCLC: small cell lung cancer; SP17: Sperm Protein 17; TAA: tumour-associated antigens; TC: thyroid cancer; TCR: T-cell-antigen receptor; TGF $\beta$ : growth factor beta; TKI: tyrosine kinase inhibitor; TME: tumour microenvironment; TNBC: TripleNegative Breast Cancer; TNF-a: tumour-necrosis factor-a; TRAIL: TNF-related apoptosis-inducing ligand; TNIBC: Triple-Negative Inflammatory Breast Cancer; Tregs: the regulatory T cells; TSA: tumour-specific antigens; UBC: urothelial bladder cancer; UC: urothelial carcinoma.

\section{Authors' contributions}

Conceived and designed the study: JW, YJ, WL. Collected the literature: ZL, YJ. Wrote the manuscript: ZL, JW. Revised the manuscript: JW. Provided funding support: JW, YJ, WL. All authors read and approved the final manuscript.

\section{Acknowledgements}

This research was supported by a Grant (SHDC12014207) from the Shen Kang Hospital Development Center Foundation, a Grant (14-E-34) from the Funded Project of Baoshan District Science and Technology Commission, Shanghai, and an individualized support project for original scientific research of the Fudan University (Ying Jiang), a grant from the National Natural Science Foundation of China (81672383), and a Grant (16PJ1408800) from the Shanghai Pujiang Program, Shanghai, China.

\section{Competing interests}

The authors declare that they have no competing interests.

\section{Availability of data and materials}

Not applicable.

\section{Consent for publication}

Not applicable.

\section{Ethics approval and consent to participate}

Not applicable.

\section{Funding}

None of the funders of this research had any influence on the design of the study, the collection, analysis and interpretation of the data, or the writing of the manuscript.

\section{Publisher's Note}

Springer Nature remains neutral with regard to jurisdictional claims in published maps and institutional affiliations.

Received: 6 February 2018 Accepted: 9 May 2018

Published online: 30 May 2018

\section{References}

1. Robert D, Schreiber LJO, Mark J. Smyth: cancer immunoediting integrating immunity's roles in cancer suppression and promotion. Science. 2011;331:1565-70.

2. Mittal D, Gubin MM, Schreiber RD, Smyth MJ. New insights into cancer immunoediting and its three component phases_elimination, equilibrium and escape. Curr Opin Immunol. 2014;27:16-25.

3. Grivennikov SI, Greten FR, Karin M. Immunity, inflammation, and cancer. Cell. 2010;140:883-99.

4. Hwang I, Nguyen N. Mechanisms of tumor-induced T cell immune suppression and therapeutics to counter those effects. Arch Pharm Res. 2015;38:1415-33.

5. Topfer K, Kempe S, Muller N, Schmitz M, Bachmann M, Cartellieri M, Schackert G, Temme A. Tumor evasion from T cell surveillance. J Biomed Biotechnol. 2011;2011:918471.

6. da Cunha A, Michelin MA, Murta EF. Pattern response of dendritic cells in the tumor microenvironment and breast cancer. World J Clin Oncol. 2014;5:495-502

7. Tan W, Zhang W, Strasner A, Grivennikov S, Cheng JQ, Hoffman $\mathrm{RM}$, Karin M. Tumour-infiltrating regulatory T cells stimulate mammary cancer metastasis through RANKL-RANK signalling. Nature. 2011;470:548-53.

8. Smyth MJ, Ngiow SF, Teng MWL. Targeting regulatory T cells in tumor immunotherapy. Immunol Cell Biol. 2014;92:473-4.

9. Chang C, Werb Z. The many faces of metalloproteases: cell growth, invasion, angiogenesis and metastasis. Trends Cell Biol. 2001;11:S37-43.

10. Kwa MJ, Adams S. Checkpoint inhibitors in triple-negative breast cancer (TNBC): where to go from here. Cancer. 2018;124:2086-103.

11. Ono M, Tsuda H, Shimizu C, Yamamoto S, Shibata T, Yamamoto H, Hirata T, Yonemori K, Ando M, Tamura K, et al. Tumor-infiltrating lymphocytes are correlated with response to neoadjuvant chemotherapy in triplenegative breast cancer. Breast Cancer Res Treat. 2012;132:793-805.

12. Kalimutho M, Parsons K, Mittal D, López JA, Srihari S, Khanna KK. Targeted therapies for triple-negative breast cancer: combating a stubborn disease. Trends Pharmacol Sci. 2015;36:822-46.

13. Denkert C, Liedtke C, Tutt A, von Minckwitz G. Molecular alterations in triple-negative breast cancer - the road to new treatment strategies. Lancet. 2017;389:2430-42.

14. Abramson VG, Lehmann BD, Ballinger TJ, Pietenpol JA. Subtyping of triple-negative breast cancer: implications for therapy. Cancer. 2015:121:8-16.

15. Theriault RL, Carlson RW, Allred C, Anderson BO, Burstein HJ, Edge SB, Farrar WB, Forero A, Giordano SH, Goldstein LJ, et al. Breast cancer, version 3.2013: featured updates to the NCCN guidelines. J Natl Compr Cancer Netw. 2013;11:753-60 (quiz 761).

16. Zumsteg ZS, Morrow M, Arnold B, Zheng JT, Zhang ZG, Robson M, Traina T, McCormick B, Powell S, Ho AY. Breast-conserving therapy achieves locoregional outcomes comparable to mastectomy in women with T1-2N0 triple-negative breast cancer. Ann Surg Oncol. 2013;20:3469-76.

17. Pilewskie M, Ho A, Orell E, Stempel M, Chen Y, Eaton A, Patil S, Morrow M. Effect of margin width on local recurrence in triple-negative breast cancer patients treated with breast-conserving therapy. Ann Surg Oncol. 2014:21:1209-14.

18. Masuda H, Baggerly KA, Wang Y, Zhang Y, Gonzalez-Angulo AM, Meric-Bernstam F, Valero V, Lehmann BD, Pietenpol JA, Hortobagyi GN, et al. Differential response to neoadjuvant chemotherapy among 7 triple-negative breast cancer molecular subtypes. Clin Cancer Res. 2013:19:5533-40.

19. Petrelli F, Coinu A, Borgonovo K, Cabiddu M, Ghilardi M, Lonati V, Barni S. The value of platinum agents as neoadjuvant chemotherapy in 
triple-negative breast cancers: a systematic review and meta-analysis. Breast Cancer Res Treat. 2014;144:223-32.

20. NCCN Clinical Practice Guidelines in Oncology: Breast Cancer. National comprehensive cancer network. 2013. Version 3.2013.

21. Bottai G, Balazs G, Nagy A, Pusztai L, Szallasi Z, Reis JS, Santarpia L. Immune signatures define and affect prognosis in triple-negative breast cancer subtypes. In: San Antonio breast cancer symposium, vol. 77. San Antonio, TX. 2017.

22. Amara D, Wolf DM, van't Veer L, Esserman L, Campbell M, Yau C. Coexpression modules identified from published immune signatures reveal five distinct immune subtypes in breast cancer. Breast Cancer Res Treat. 2017;161:41-50

23. Keir ME, Butte MJ, Freeman GJ, Sharpe AH. PD-1 and its ligands in tolerance and immunity. Annu Rev Immunol. 2008;26:677-704.

24. Dong HD, Strome SE, Salomao DR, Tamura H, Hirano F, Flies DB, Roche PC, Lu J, Zhu GF, Tamada K, et al. Tumor-associated B7-H1 promotes T-cell apoptosis: a potential mechanism of immune evasion. Nat Med. 2002:8:793-800.

25. Ishida Y, Agata Y, Shibahara K, Honjo T. Induced expression of PD-1, a novel member of the immunoglobulin gene superfamily, upon programmed cell death. EMBO J. 1992;11:3887-95.

26. Park IH, Yang HN, Lee KJ, Kim TS, Lee ES, Jung SY, Kwon Y, Kong SY. Tumor-derived IL-18 induces PD-1 expression on immunosuppressive NK cells in triple-negative breast cancer. Oncotarget. 2017;8:32722-30

27. Flies DB, Chen L. The new B7s: playing a pivotal role in tumor immunity J Immunother. 2007;30:251-60.

28. Gray MJ, Gong J, Hatch MM, Nguyen V, Hughes CC, Hutchins JT, Freimark BD. Phosphatidylserine-targeting antibodies augment the anti-tumorigenic activity of anti-PD-1 therapy by enhancing immune activation and downregulating pro-oncogenic factors induced by T-cell checkpoint inhibition in murine triple-negative breast cancers. Breast Cancer Res. 2016;18:50.

29. Tumeh PC, Harview CL, Yearley JH, Shintaku IP, Taylor EJ, Robert L, Chmielowski B, Spasic M, Henry G, Ciobanu V, et al. PD-1 blockade induces responses by inhibiting adaptive immune resistance. Nature. 2014;515:568-71.

30. Mittendorf EA, Philips AV, Meric-Bernstam F, Qiao N, Wu Y, Harrington S, Su XP, Wang Y, Gonzalez-Angulo AM, Akcakanat A, et al. PD-L1 expression in triple-negative breast cancer. Cancer Immunol Res. 2014:2:361-70.

31. Schutz F, Stefanovic S, Mayer L, von Au A, Domschke C, Sohn C. PD-1/ PD-L1 pathway in breast cancer. Oncol Res Treat. 2017:40:294-7.

32. Garcia-Teijido P, Cabal ML, Fernandez IP, Perez YF. Tumor-infiltrating lymphocytes in triple negative breast cancer: the future of immune targeting. Clin Med Insights Oncol. 2016;10:31-9.

33. Topalian SL, Hodi FS, Brahmer JR, Gettinger SN, Smith DC, McDermott DF, Powderly JD, Carvajal RD, Sosman JA, Atkins MB, et al. Safety, activity, and immune correlates of anti-PD-1 antibody in cancer. N Engl J Med. 2012;366:2443-54.

34. Brahmer JR, Tykodi SS, Chow LQM, Hwu WJ, Topalian SL, Hwu P, Drake CG, Camacho LH, Kauh J, Odunsi K, et al. Safety and activity of anti-PD-L1 antibody in patients with advanced cancer. N Engl J Med. 2012;366:2455-65.

35. Anti-PD-1 cancer star nivolumab wins world's first regulatory approval. https://www.fiercebiotech.com/biotech/anti-pd-1-cancer-star-nivol umab-wins-world-s-first-regulatory-approval. Accessed 7 July 2014.

36. Nanda R, Chow LQ, Dees EC, Berger R, Gupta S, Geva R, Pusztai L, Pathiraja K, Aktan G, Cheng JD, et al. Pembrolizumab in patients with advanced triple-negative breast cancer: phase Ib KEYNOTE-012 study. J Clin Oncol. 2016;34:2460-7.

37. Li CW, Lim SO, Chung EM, Kim YS, Park AH, Yao J, Cha JH, Xia W, Chan LC Kim T, et al. Eradication of triple-negative breast cancer cells by targeting glycosylated PD-L1. Cancer Cell. 2018;33(187-201):e110.

38. Brockwell NK, Owen KL, Zanker D, Spurling A, Rautela J, Duivenvoorden HM, Baschuk N, Caramia F, Loi S, Darcy PK, et al. Neoadjuvant interferons: critical for effective PD-1-based immunotherapy in TNBC. Cancer Immunol Res. 2017:5:871-84.

39. Ghebeh $\mathrm{H}$, Barhoush E, Tulbah A, Elkum N, Al-Tweigeri T, Dermime S. FOXP3 + Tregs and B7-H1 +/PD-1+Tlymphocytes co-infiltrate the tumor tissues of high-risk breast cancer patients: implication for immunotherapy. BMC Cancer. 2008;8:57.
40. Li Z, Dong P, Ren M, Song Y, Qian X, Yang Y, Li S, Zhang X, Liu F. PD-L1 expression is associated with tumor FOXP3(+) regulatory T-cell infiltration of breast cancer and poor prognosis of patient. J Cancer. 2016;7:784-93.

41. Toor SM, Syed Khaja AS, Alkurd I, Elkord E. In-vitro effect of pembrolizumab on different T regulatory cell subsets. Clin Exp Immunol. 2018;191:189-97.

42. Aguiar PN Jr, Santoro IL, Tadokoro H, de Lima Lopes G, Filardi BA, Oliveira P, Mountzios G, de Mello RA. The role of PD-L1 expression as a predictive biomarker in advanced non-small-cell lung cancer: a network meta-analysis. Immunotherapy. 2016;8:479-88.

43. Leach DR, Krummel MF, Allison JP. Enhancement of antitumor immunity by CTLA-4 blockade. Science. 1996;271:1734-6.

44. Couzin-Frankel J. Cancer immunotherapy. Science. 2013;342:1432-3.

45. Prieto PA, Yang JC, Sherry RM, Hughes MS, Kammula US, White DE, Levy CL, Rosenberg SA, Phan GQ. CTLA-4 blockade with ipilimumab: longterm follow-up of 177 patients with metastatic melanoma. Clin Cancer Res. 2012;18:2039-47.

46. Tanaka A, Sakaguchi S. Regulatory T cells in cancer immunotherapy. Cell Res. 2017:27:109-18.

47. Hartman ZC, Crosby EJ, Wei JP, Yang XY, Lei GJ, Wang T, Liu CX, Agarwal P, Morse MS, Lyerly HK. CTLA-4 and PD-1 checkpoint inhibitors enhance individually tailored adaptive antitumor immune responses to overcome tumor immunosuppression and effectively treat triple-negative breast cancer. In: San Antonio breast cancer symposium, vol. 77. San Antonio, TX. 2017.

48. Liu LN, Wang YH, Miao L, Liu Q, Musetti S, Li J, Huang L. Combination immunotherapy of MUC1 mRNA nano-vaccine and CTLA-4 blockade effectively inhibits growth of triple negative breast cancer. Mol Ther. 2018;26:45-55.

49. Stanton SE, Adams S, Disis ML. Variation in the incidence and magnitude of tumor-infiltrating lymphocytes in breast cancer subtypes: a systematic review. JAMA Oncol. 2016;2:1354-60.

50. Ladoire S, Arnould L, Apetoh L, Coudert B, Martin F, Chauffert B, Fumoleau P, Ghiringhelli F. Pathologic complete response to neoadjuvant chemotherapy of breast carcinoma is associated with the disappearance of tumor-infiltrating foxp3+ regulatory T cells. Clin Cancer Res. 2008:14:2413-20.

51. Taylor NA, Vick SC, Iglesia MD, Brickey WJ, Midkiff BR, McKinnon KP, Reisdorf S, Anders CK, Carey LA, Parker JS, et al. Treg depletion potentiates checkpoint inhibition in claudin-low breast cancer. J Clin Invest. 2017:127:3472-83.

52. Parry RV, Chemnitz JM, Frauwirth KA, Lanfranco AR, Braunstein I, Kobayashi SV, Linsley PS, Thompson CB, Riley JL. CTLA-4 and PD-1 receptors inhibit T-cell activation by distinct mechanisms. Mol Cell Biol. 2005;25:9543-53.

53. Tanvetyanon T, Gray JE, Antonia SJ. PD-1 checkpoint blockade alone or combined PD-1 and CTLA-4 blockade as immunotherapy for lung cancer? Expert Opin Biol Ther. 2017;17:305-12.

54. Curran MA, Montalvo W, Yagita H, Allison JP. PD-1 and CTLA-4 combination blockade expands infiltrating $T$ cells and reduces regulatory $T$ and myeloid cells within B16 melanoma tumors. Proc Natl Acad Sci USA. 2010;107:4275-80.

55. de Coana YP, Choudhury A, Kiessling R. Checkpoint blockade for cancer therapy: revitalizing a suppressed immune system. Trends Mol Med. 2015;21:482-91.

56. Duraiswamy J, Kaluza KM, Freeman GJ, Coukos G. Dual blockade of PD-1 and CTLA-4 combined with tumor vaccine effectively restores T-cell rejection function in tumors. Cancer Res. 2013;73:3591-603.

57. Nolan E, Savas P, Policheni AN, Darcy PK, Vaillant F, Mintoff CP, Dushyanthen S, Mansour M, Pang JMB, Fox SB, et al. Combined immune checkpoint blockade as a therapeutic strategy for BRCA1-mutated breast cancer. Sci Transl Med. 2017;9:12.

58. Costa R, Shah AN, Santa-Maria CA, Cruz MR, Mahalingam D, Carneiro BA, Chae YK, Cristofanilli M, Gradishar WJ, Giles FJ. Targeting epidermal growth factor receptor in triple negative breast cancer: new discoveries and practical insights for drug development. Cancer Treat Rev. 2017:53:111-9.

59. Huang WC, Chen YJ, Li LY, Wei YL, Hsu SC, Tsai SL, Chiu PC, Huang WP, Wang YN, Chen $\mathrm{CH}$, et al. Nuclear translocation of epidermal growth factor receptor by Akt-dependent phosphorylation enhances breast 
cancer-resistant protein expression in gefitinib-resistant cells. J Biol Chem. 2011;286:20558-68.

60. Lo HW, Hsu SC, Ali-Seyed M, Gunduz M, Xia WY, Wei YK, Bartholomeusz G, Shih JY, Hung MC. Nuclear interaction of EGFR and STAT3 in the activation of the iNOS/NO pathway. Cancer Cell. 2005;7:575-89.

61. Suzuki E, Yamaguchi A, Kataoka TR, Hirata M, Kawaguchi K, Nishie M, Toi M. EGFR is transferred from triple negative breast cancer cells to immune cells via trogocytosis and expression of EGFR on immune cells is associated with high tumor grade of triple negative breast cancer patients. In: 106th annual meeting of the American-association-forcancer-research (AACR), vol. 75. Philadelphia, PA. 2015.

62. Changavi AA, Shashikala A, Ramji AS. Epidermal growth factor receptor expression in triple negative and nontriple negative breast carcinomas. J Lab Phys. 2015;7:79-83.

63. Joly E, Hudrisier D. What is trogocytosis and what is its purpose? Nat Immunol. 2003;4:815.

64. Yamaguchi A, Suzuki E, Kawaguchi K, Nishie M, Tsuda M, Toi M. Direct immune cell contact to basal-like triple negative breast cancer cells evokes downregulation of EGFR and PD-L1. In: AACR 107th annual meeting on bioinformatics and systems biology, vol. 76. New Orleans, LA. 2016.

65. Lim SO, Li CW, Xia WY, Lee HH, Chang SS, Shen J, Hsu JL, Raftery D, Djukovic D, Gu HW, et al. EGFR signaling enhances aerobic glycolysis in triple-negative breast cancer cells to promote tumor growth and immune escape. Cancer Res. 2016;76:1284-96.

66. Baselga J, Norton L, Masui H, Pandiella A, Coplan K, Miller WH Jr, Mendelsohn J. Antitumor effects of doxorubicin in combination with anti-epidermal growth factor receptor monoclonal antibodies. J Natl Cancer Inst. 1993;85:1327-33.

67. Baselga J, Gomez P, Greil R, Braga S, Climent MA, Wardley AM, Kaufman B, Stemmer SM, Pego A, Chan A, et al. Randomized phase Il study of the anti-epidermal growth factor receptor monoclonal antibody cetuximab with cisplatin versus cisplatin alone in patients with metastatic triplenegative breast cancer. J Clin Oncol. 2013;31:2586-92.

68. Crozier JA, Advani PP, LaPlant B, Hobday T, Jaslowski AJ, Moreno-Aspitia A, Perez EA. N0436 (alliance): a phase II trial of irinotecan with cetuximab in patients with metastatic breast cancer previously exposed to anthracycline and/or taxane-containing therapy. Clin Breast Cancer. 2016;16:23-30.

69. Nabholtz JM, Abrial C, Mouret-Reynier MA, Dauplat MM, Weber B, Gligorov J, Forest AM, Tredan O, Vanlemmens L, Petit T, et al. Multicentric neoadjuvant phase II study of panitumumab combined with an anthracycline/taxane-based chemotherapy in operable triple-negative breast cancer: identification of biologically defined signatures predicting treatment impact. Ann Oncol. 2014;25:1570-7.

70. Ferraro DA, Gaborit N, Maron R, Cohen-Dvashi H, Porat Z, Pareja F, Lavi S, Lindzen M, Ben-Chetrit N, Sela M, Yarden Y. Inhibition of triple-negative breast cancer models by combinations of antibodies to EGFR. Proc Natl Acad Sci USA. 2013:110:1815-20.

71. El Guerrab A, Bamdad M, Kwiatkowski F, Bignon Y-J, Penault-Llorca F, Aubel C. Anti-EGFR monoclonal antibodies and EGFR tyrosine kinase inhibitors as combination therapy for triple-negative breast cancer. Oncotarget. 2016;7:73618-37.

72. Pollack BP, Sapkota B, Cartee TV. Epidermal growth factor receptor inhibition augments the expression of MHC class I and II genes. Clin Cancer Res. 2011;17:4400-13.

73. Lastwika KJ, Wilson W 3rd, Li QK, Norris J, Xu H, Ghazarian SR, Kitagawa H, Kawabata S, Taube JM, Yao S, et al. Control of PD-L1 expression by oncogenic activation of the AKT-mTOR pathway in non-small cell lung cancer. Cancer Res. 2016;76:227-38.

74. Concha-Benavente F, Srivastava RM, Trivedi S, Lei Y, Chandran U, Seethala RR, Freeman GJ, Ferris RL. Identification of the cell-intrinsic and -extrinsic pathways downstream of EGFR and IFNgamma that induce PD-L1 expression in head and neck cancer. Cancer Res. 2016;76:1031-43.

75. Wang S, Zhang Y, Wang Y, Ye P, Li J, Li H, Ding Q, Xia J. Amphiregulin confers regulatory $T$ cell suppressive function and tumor invasion via the EGFR/GSK-3beta/Foxp3 Axis. J Biol Chem. 2016;291:21085-95.

76. Li X, Lian Z, Wang S, Xing LG, Yu JM. Interactions between EGFR and PD-1/PD-L1 pathway: implications for treatment of NSCLC. Cancer Lett. 2018:418:1-9.
77. Santabarbara G, Maione P, Rossi A, Palazzolo G, Gridelli C. Novel immunotherapy in the treatment of advanced non-small cell lung cancer. Expert Rev Clin Pharmacol. 2016;9:1571-81.

78. Kowanetz M, Ferrara N. Vascular endothelial growth factor signaling pathways: therapeutic perspective. Clin Cancer Res. 2006;12:5018-22.

79. Su JC, Mar AC, Wu SH, Tai WT, Chu PY, Wu CY, Tseng LM, Lee TC, Chen KF, Liu CY, et al. Disrupting VEGF-A paracrine and autocrine loops by targeting SHP-1 suppresses triple negative breast cancer metastasis. Sci Rep. 2016:6:28888.

80. Genentech I. Avastin full prescribing information. In: Genecom; 2016.

81. Miles DW, Chan A, Dirix LY, Cortes J, Pivot X, Tomczak P, Delozier T, Sohn JH, Provencher L, Puglisi F, et al. Phase III study of bevacizumab plus docetaxel compared with placebo plus docetaxel for the first-line treatment of human epidermal growth factor receptor 2-negative metastatic breast cancer. J Clin Oncol. 2010;28:3239-47.

82. Robert NJ, Dieras V, Glaspy J, Brufsky AM, Bondarenko I, Lipatov ON, Perez EA, Yardley DA, Chan SY, Zhou X, et al. RIBBON-1: randomized, double-blind, placebo-controlled, phase III trial of chemotherapy with or without bevacizumab for first-line treatment of human epidermal growth factor receptor 2-negative, locally recurrent or metastatic breast cancer. J Clin Oncol. 2011;29:1252-60.

83. Miller K, Wang M, Gralow J, Dickler M, Cobleigh M, Perez EA, Shenkier T, Cella D, Davidson NE. Paclitaxel plus bevacizumab versus paclitaxel alone for metastatic breast cancer. N Engl J Med. 2007;357:2666-76.

84. Bell R, Brown J, Parmar M, Toi M, Suter T, Steger GG, Pivot X, Mackey J, Jackisch C, Dent R, et al. Final efficacy and updated safety results of the randomized phase III BEATRICE trial evaluating adjuvant bevacizumabcontaining therapy in triple-negative early breast cancer. Ann Oncol. 2017;28:754-60.

85. Elizabeth P, Yin M, Peters CG, Lee CR, Brown D, Xu P, Man S, Jayaraman $\mathrm{L}$, Rohde $\mathrm{E}$, Chow $\mathrm{A}$, et al. Preclinical efficacy of bevacizumab with CRLX101, an investigational nanoparticle-drug conjugate, in treatment of metastatic triple-negative breast cancer. Cancer Res. 2016;76:4493-503.

86. Gamucci T, Mentuccia L, Natoli C, Sperduti I, Cassano A, Michelotti A, Di Lauro L, Sergi D, Fabi A, Sarobba MG, et al. A real-world multicentre retrospective study of paclitaxel-bevacizumab and maintenance therapy as first-line for HER2-negative metastatic breast cancer. J Cell Physiol. 2017;232:1571-8.

87. Bear HD, Tang G, Rastogi P, Geyer CE Jr, Liu Q, Robidoux A, Baez-Diaz L, Brufsky AM, Mehta RS, Fehrenbacher L, et al. Neoadjuvant plus adjuvant bevacizumab in early breast cancer (NSABP B-40 [NRG Oncology]): secondary outcomes of a phase 3 , randomised controlled trial. Lancet Oncol. 2015;16:1037-48.

88. Ferrero JM, Hardy-Bessard AC, Capitain O, Lortholary A, Salles B, Follana P, Herve R, Deblock M, Dauba J, Atlassi M, Largillier R. Weekly paclitaxel, capecitabine, and bevacizumab with maintenance capecitabine and bevacizumab as first-line therapy for triple-negative, metastatic, or locally advanced breast cancer: results from the GINECO A-TaXel phase 2 study. Cancer. 2016;122:3119-26.

89. Dikov MM, Ohm JE, Ray N, Tchekneva EE, Burlison J, Moghanaki D, Nadaf S, Carbone DP. Differential roles of vascular endothelial growth factor receptors 1 and 2 in dendritic cell differentiation. J Immunol. 2005;174:215-22.

90. Voron T, Colussi O, Marcheteau E, Pernot S, Nizard M, Pointet AL, Latreche S, Bergaya S, Benhamouda N, Tanchot C, et al. VEGF-A modulates expression of inhibitory checkpoints on CD8+T cells in tumors. J Exp Med. 2015;212:139-48.

91. Nadal R, Amin A, Geynisman DM, Voss MH, Weinstock M, Doyle J, Zhang Z, Viudez A, Plimack ER, McDermott DF, et al. Safety and clinical activity of vascular endothelial growth factor receptor (VEGFR)-tyrosine kinase inhibitors after programmed cell death 1 inhibitor treatment in patients with metastatic clear cell renal cell carcinoma. Ann Oncol. 2016;27:1304-11.

92. Wallin JJ, Bendell JC, Funke R, Sznol M, Korski K, Jones S, Hernandez G, Mier J, He X, Hodi FS, et al. Atezolizumab in combination with bevacizumab enhances antigen-specific T-cell migration in metastatic renal cell carcinoma. Nat Commun. 2016;7:12624

93. Yasuda S, Sho M, Yamato I, Yoshiji H, Wakatsuki K, Nishiwada S, Yagita H, Nakajima Y. Simultaneous blockade of programmed death 1 and vascular endothelial growth factor receptor 2 (VEGFR2) 
induces synergistic anti-tumour effect in vivo. Clin Exp Immunol. 2013;172:500-6.

94. Le Du F, Eckhardt BL, Lim B, Litton JK, Moulder S, Meric-Bernstam F, Gonzalez-Angulo AM, Ueno NT. Is the future of personalized therapy in triple-negative breast cancer based on molecular subtype? Oncotarget. 2015;6:12890-908.

95. Domagala P, Huzarski T, Lubinski J, Gugala K, Domagala W. PARP-1 expression in breast cancer including BRCA1-associated, triple negative and basal-like tumors: possible implications for PARP-1 inhibitor therapy. Breast Cancer Res Treat. 2011;127:861-9.

96. Hill SJ, Clark AP, Silver DP, Livingston DM. BRCA1 pathway function in basal-like breast cancer cells. Mol Cell Biol. 2014;34:3828-42.

97. Lehmann BD, Bauer JA, Chen X, Sanders ME, Chakravarthy AB, Shyr Y, Pietenpol JA. Identification of human triple-negative breast cancer subtypes and preclinical models for selection of targeted therapies. J Clin Invest. 2011;121:2750-67.

98. Geenen JJJ, Linn SC, Beijnen JH, Schellens JHM. PARP inhibitors in the treatment of triple-negative breast cancer. Clin Pharmacokinet. 2018;57:427-37.

99. Jiao S, Xia W, Yamaguchi H, Wei Y, Chen MK, Hsu JM, Hsu JL, Yu WH, Du Y, Lee HH, et al. PARP inhibitor upregulates PD-L1 expression and enhances cancer-associated immunosuppression. Clin Cancer Res. 2017:23:3711-20

100. Shay G, Lynch CC, Fingleton B. Moving targets: emerging roles for MMPs in cancer progression and metastasis. Matrix Biol. 2015;44-46:200-6.

101. Beaty BT, Condeelis J. Digging a little deeper: the stages of invadopodium formation and maturation. Eur J Cell Biol. 2014;93:438-44.

102. Devy L, Huang L, Naa L, Yanamandra N, Pieters H, Frans N, Chang E, Tao Q, Vanhove M, Lejeune A, et al. Selective inhibition of matrix metalloproteinase-14 blocks tumor growth, invasion, and angiogenesis. Cancer Res. 2009;69:1517-26.

103. Venning FA, Wullkopf L, Erler JT. Targeting ECM disrupts cancer progression. Front Oncol. 2015;5:224.

104. Tetu B, Brisson J, Wang CS, Lapointe H, Beaudry G, Blanchette C, Trudel D. The influence of MMP-14, TIMP-2 and MMP-2 expression on breast cancer prognosis. Breast Cancer Res. 2006;8:R28.

105. Ager El, Kozin SV, Kirkpatrick ND, Seano G, Kodack DP, Askoxylakis V, Huang Y, Goel S, Snuderl M, Muzikansky A, et al. Blockade of MMP14 activity in murine breast carcinomas: implications for macrophages, vessels, and radiotherapy. J Natl Cancer Inst. 2015;107:djv017.

106. Botkjaer KA, Kwok HF, Terp MG, Karatt-Vellatt A, Santamaria S, McCafferty J, Andreasen PA, Itoh Y, Ditzel HJ, Murphy G. Development of a specific affinity-matured exosite inhibitor to MT1-MMP that efficiently inhibits tumor cell invasion in vitro and metastasis in vivo. Oncotarget. 2016;7:16773-92.

107. Lopez T, Nam DH, Kaihara E, Mustafa Z, Ge X. Identification of highly selective MMP-14 inhibitory Fabs by deep sequencing. Biotechnol Bioeng. 2017;114:1140-50.

108. Ling BB, Watt K, Banerjee S, Newsted D, Truesdell P, Adams J, Sidhu SS, Craig AWB. A novel immunotherapy targeting MMP-14 limits hypoxia, immune suppression and metastasis in triple-negative breast cancer models. Oncotarget. 2017:8:58372-85.

109. Dudley ME, Rosenberg SA. Adoptive-cell-transfer therapy for the treatment of patients with cancer. Nat Rev Cancer. 2003;3:666-U662.

110. June $\mathrm{CH}$. Adoptive T cell therapy for cancer in the clinic. J Clin Invest. 2007;117:1466-76

111. Denman CJ, Senyukov VV, Somanchi SS, Phatarpekar PV, Kopp LM, Johnson JL, Singh H, Hurton L, Maiti SN, Huls MH, et al. Membranebound IL-21 promotes sustained ex vivo proliferation of human natural killer cells. PLoS ONE. 2012;7:e30264.

112. Fujisaki H, Kakuda H, Shimasaki N, Imai C, Ma J, Lockey T, Eldridge P, Leung WH, Campana D. Expansion of highly cytotoxic human natural killer cells for cancer cell therapy. Cancer Res. 2009;69:4010-7.

113. Ames E, Murphy WJ. Advantages and clinical applications of natural killer cells in cancer immunotherapy. Cancer Immunol Immunother. 2014;63:21-8

114. Shenouda MM, Gillgrass A, Nham T, Hogg R, Lee AJ, Chew MV, Shafaei M, Aarts C, Lee DA, Hassell J, et al. Ex vivo expanded natural killer cells from breast cancer patients and healthy donors are highly cytotoxic against breast cancer cell lines and patient-derived tumours. Breast Cancer Res. 2017:19:76.

115. Chodon T, Comin-Anduix B, Chmielowski B, Koya RC, Wu Z, Auerbach M, $\mathrm{Ng}$ C, Avramis E, Seja E, Villanueva A, et al. Adoptive transfer of MART-1 T-cell receptor transgenic lymphocytes and dendritic cell vaccination in patients with metastatic melanoma. Clin Cancer Res. 2014;20:2457-65.

116. Rosenberg SA, Restifo NP. Adoptive cell transfer as personalized immunotherapy for human cancer. Science. 2015;348:62-8.

117. Gross G, Gorochov G, Waks T, Eshhar Z. Generation of effector T cells expressing chimeric $T$ cell receptor with antibody type-specificity. Transplant Proc. 1989;21:127-30.

118. Kochenderfer JN, Yu Z, Frasheri D, Restifo NP, Rosenberg SA. Adoptive transfer of syngeneic $T$ cells transduced with a chimeric antigen receptor that recognizes murine CD19 can eradicate lymphoma and normal B cells. Blood. 2010;116:3875-86.

119. Yan L, Chen HX. Cancer immunotherapy. Chin J Cancer. 2014;33:413-5.

120. Adachi K, Kano Y, Nagai T, Okuyama N, Sakoda Y, Tamada K. IL-7 and CCL19 expression in CAR-T cells improves immune cell infiltration and CAR-T cell survival in the tumor. Nat Biotechnol. 2018;36:346-51.

121. Mukherjee P, Zhou RU, Yazdanifar M, Roy LD. Development and future of CART cell therapy for pancreatic ductal adenocarcinoma and triple negative breast cancer. In AACR international conference: New frontiers in cancer research, vol. 77, Cape Town, South Africa, 18-22 January 2017. https://doi.org/10.1158/1538-7445.

122. Hassan R, Thomas A, Alewine C, Le DT, Jaffee EM, Pastan I. Mesothelin immunotherapy for cancer: ready for prime time? J Clin Oncol. 2016;34:4171.

123. Byrd TT, Fousek K, Pignata A, Szot C, Samaha H, Seaman S, Dobrolecki L, Salsman VS, Oo HZ, Bielamowicz K, et al. TEM8/ANTXR1-specific CART cells as a targeted therapy for triple-negative breast cancer. Cancer Res. 2018:78:489-500.

124. Song DG, Ye Q, Poussin M, Chacon JA, Figini M, Powell DJ Jr. Effective adoptive immunotherapy of triple-negative breast cancer by folate receptor-alpha redirected CART cells is influenced by surface antigen expression level. J Hematol Oncol. 2016:9:56.

125. Hamilton DH, Roselli M, Ferroni P, Costarelli L, Cavaliere F, Taffuri M, Palena C, Guadagni F. Brachyury, a vaccine target, is overexpressed in triple-negative breast cancer. Endocr Relat Cancer. 2016;23:783-96.

126. Ping Y, Liu C, Zhang Y. T-cell receptor-engineered T cells for cancer treatment: current status and future directions. Protein Cell. 2018;9:254-66.

127. Rapoport AP, Stadtmauer EA, Binder-Scholl GK, Goloubeva O, Vogl DT, Lacey SF, Badros AZ, Garfall A, Weiss B, Finklestein J, et al. NY-ESO1-specific TCR-engineered T cells mediate sustained antigen-specific antitumor effects in myeloma. Nat Med. 2015;21:914-21.

128. Li Q, Liu M, Wu M, Zhou X, Wang S, Hu Y, Wang Y, He Y, Zeng X, Chen J, et al. PLAC1-specific TCR-engineered T cells mediate antigen-specific antitumor effects in breast cancer. Oncol Lett. 2018;15:5924-32.

129. Jin J, Gkitsas N, Fellowes VS, Ren J, Feldman SA, Hinrichs CS, Stroncek DF, Highfill SL. Enhanced clinical-scale manufacturing of TCR transduced T-cells using closed culture system modules. JTransI Med. 2018;16:13.

130. Legut M, Dolton G, Mian AA, Ottmann OG, Sewell AK. CRISPR-mediated TCR replacement generates superior anticancer transgenic $T$ cells. Blood. 2018;131:311-22

131. Perez C, Jukica A, Listopad JJ, Anders K, Kuhl AA, Loddenkemper C, Blankenstein T, Charo J. Permissive expansion and homing of adoptively transferred T cells in tumor-bearing hosts. Int J Cancer. 2015:137:359-71.

132. Moon EK, Ranganathan R, Eruslanov E, Kim S, Newick K, O'Brien S, Lo A, Liu X, Zhao Y, Albelda SM. Blockade of programmed death 1 augments the ability of human T cells engineered to target NY-ESO-1 to control tumor growth after adoptive transfer. Clin Cancer Res. 2016;22:436-47.

133. Aaltomaa S, Lipponen P, Eskelinen M, Kosma VM, Marin S, Alhava E, Syrjanen K. Lymphocyte infiltrates as a prognostic variable in female breast-cancer. Eur J Cancer. 1992;28A:859-64.

134. Clemente CG, Mihm MG, Bufalino R, Zurrida S, Collini P, Cascinelli $N$. Prognostic value of tumor infiltrating lymphocytes in the vertical growth phase of primary cutaneous melanoma. Cancer. 1996:77:1303-10.

135. Prall F, Duhrkop T, Weirich V, Ostwald C, Lenz P, Nizze H, Barten M. Prognostic role of CD8+ tumor-infiltrating lymphocytes in stage III 
colorectal cancer with and without microsatellite instability. Hum Pathol. 2004;35:808-16.

136. Halama N, Michel S, Kloor M, Zoernig I, Benner A, Spille A, Pommerencke T, Doeberitz MV, Folprecht G, Luber B, et al. Localization and density of immune cells in the invasive margin of human colorectal cancer liver metastases are prognostic for response to chemotherapy. Cancer Res. 2011;71:5670-7.

137. Sharma P, Shen Y, Wen SJ, Yamada S, Jungbluth AA, Gnjatic S, Bajorin DF, Reuter VE, Herr H, Old LJ, Sato E. CD8 tumor-infiltrating lymphocytes are predictive of survival in muscle-invasive urothelial carcinoma. Proc Natl Acad Sci USA. 2007;104:3967-72.

138. Matsumoto H, Koo SL, Dent R, Tan PH, lqbal J. Role of inflammatory infiltrates in triple negative breast cancer. J Clin Pathol. 2015;68:506-10.

139. Fridman WH, Galon J, Pages F, Tartour E, Sautes-Fridman C, Kroemer G. Prognostic and predictive impact of intra- and peritumoral immune infiltrates. Cancer Res. 2011;71:5601-5.

140. Gruosso T, Gigoux M, Bertos N, Manem VSK, Guiot MC, Buisseret L, Salgado R, Van den Eyden G, Haibe-Kains B, Park M. Distinct immune microenvironments stratify triple-negative breast cancer and predict outcome. In: IMPAKT breast cancer conference, vol. 28. Brussels, Belgium. 2017. p. 50P.

141. Karn T, Jiang T, Hatzis C, Sanger N, El-Balat A, Holtrich U, Becker S, Bianchini G, Pusztai L. Immune sculpting of the triple negative breast cancer genome. In: San Antonio breast cancer symposium, vol. 77. San Antonio, TX. 2017. p. S1-07.

142. Bottai G, Raschioni C, Losurdo A, Di Tommaso L, Roncalli M, Santarpia L. Immune balance between tumor-infiltrating lymphocytes and tumorassociated macrophages impacts the outcome of triple negative breast cancer patients. In: 38th annual CTRC-AACR San Antonio breast cancer symposium, vol. 76. San Antonio, TX. 2016. p. P4-04-06.

143. Pan K, Guan XX, Li YQ, Zhao JJ, Li JJ, Qiu HJ, Weng DS, Wang QJ, Liu Q, Huang LX, et al. Clinical activity of adjuvant cytokine-induced killer cell immunotherapy in patients with post-mastectomy triple-negative breast cancer. Clin Cancer Res. 2014;20:3003-11.

144. Gajewski TF, Schumacher T. Cancer immunotherapy. Curr Opin Immunol. 2013;25:259-60.

145. Mirandola L, Pedretti E, Figueroa JA, Chiaramonte R, Colombo M, Chapman C, Grizzi F, Patrinicola F, Kast WM, Nguyen DD, et al. Cancer testis antigen Sperm Protein 17 as a new target for triple negative breast cancer immunotherapy. Oncotarget. 2017;8:74378-90.

146. Curigliano G, Viale G, Ghioni M, Jungbluth AA, Bagnardi V, Spagnoli GC, Neville AM, Nole F, Rotmensz N, Goldhirsch A. Cancer-testis antigen expression in triple-negative breast cancer. Ann Oncol. 2011;22:98-103.

147. Richardson RT, Yamasaki N, Orand MG. Sequence of a rabbit sperm zona-pellucida binding-protein and localization during the acrosome reaction. Dev Biol. 1994:165:688-701.

148. Chiriva-Internati M, Gagliano N, Donetti E, Costa F, Grizzi F, Franceschini B, Albani E, Levi-Setti PE, Gioia M, Jenkins M, et al. Sperm protein 17 is expressed in the sperm fibrous sheath. J Transl Med. 2009;7:61.

149. Chiriva-Internati M, Wang Z, Salati E, Wroblewski D, Lim SH. Successful generation of sperm protein 17 (Sp17)-specific cytotoxic T lymphocytes from normal donors: implication for tumor-specific adoptive immunotherapy following allogeneic stem cell transplantation for Sp17-positive multiple myeloma. Scand J Immunol. 2002;56:429-33.

150. Chiriva-Internati M, Weidanz JA, Yu Y, Frezza EE, Jenkins MR, Kennedy RC, Cobos E, Kast WM. Sperm protein 17 is a suitable target for adoptive T-cell-based immunotherapy in human ovarian cancer. J Immunother. 2008:31:693-703.

151. Gupta G, Sharma R, Chattopadhyay TK, Gupta SD, Ralhan R. Clinical significance of sperm protein 17 expression and immunogenicity in esophageal cancer. Int J Cancer. 2007;120:1739-47.

152. Grizzi F, Gaetani P, Franceschini B, Di leva A, Colombo P, Ceva-Grimaldi G, Bollati A, Frezza EE, Cobos E, Rodriguez y Baena R, et al. Sperm protein 17 is expressed in human nervous system tumours. BMC Cancer. 2006;6:23.

153. Li FQ, Liu Q, Han YL, Wu B, Yin HL. Sperm protein 17 is highly expressed in endometrial and cervical cancers. BMC Cancer. 2010;10:429.

154. Mirandola L, Figueroa JA, Phan TT, Grizzi F, Kim M, Rahman RL, Jenkins MR, Cobos E, Jumper C, Alalawi R, Chiriva-Internati M. Novel antigens in non-small cell lung cancer: SP17, AKAP4, and PTTG1 are potential immunotherapeutic targets. Oncotarget. 2015;6:2812-26.
155. Chiriva-Internati M, Wang ZQ, Salati E, Bumm K, Barlogie B, Lim SH. Sperm protein 17 (Sp17) is a suitable target for immunotherapy of multiple myeloma. Blood. 2002;100:961-5.

156. Arnaboldi F, Menon A, Menegola E, Di Renzo F, Mirandola L, Grizzi F, Figueroa JA, Cobos E, Jenkins M, Barajon I, Chiriva-Internati M. Sperm Protein 17 is an oncofetal antigen: a lesson from a murine model. Int Rev Immunol. 2014:33:367-74.

157. Dadabayev AR, Wang ZQ, Zhang Y, Zhang J, Robinson WR, Lim SH. Cancer immunotherapy targeting Sp17: when should the laboratory findings be translated to the clinics? Am J Hematol. 2005;80:6-11.

158. Ademuyiwa FO, Bshara W, Attwood K, Morrison C, Edge SB, Karpf AR, James SA, Ambrosone CB, O'Connor TL, Levine EG, et al. NY-ESO-1 cancer testis antigen demonstrates high immunogenicity in triple negative breast cancer. PLoS ONE. 2012;7:e38783.

159. Lee HJ, Kim JY, Song IH, Park IA, Yu JH, Gong G. Expression of NY-ESO-1 in triple-negative breast cancer is associated with tumor-infiltrating lymphocytes and a good prognosis. Oncology. 2015;89:337-44.

160. Takahashi R, Toh U, Iwakuma N, Takenaka M, Otsuka H, Furukawa M, Fujii T, Seki N, Kawahara A, Kage M, et al. Feasibility study of personalized peptide vaccination for metastatic recurrent triple-negative breast cancer patients. Breast Cancer Res. 2014;16:R70.

161. Piechocki MP, Wu GS, Jones RF, Jacob JB, Gibson H, Ethier SP, Abrams J, Yagita $H$, Venuprasad K, Wei WZ. Induction of proapoptotic antibodies to triple-negative breast cancer by vaccination with TRAIL death receptor DR5 DNA. Int J Cancer. 2012;131:2562-72.

162. Liu XY, Hu JX, Cao WH, Qu HL, Wang Y, Ma ZL, Li FN. Effects of two different immunotherapies on triple negative breast cancer in animal model. Cell Immunol. 2013;284:111-8.

163. O'Shaughnessy J, Roberts LK, Smith JL, Levin MK, Timis R, Finholt JP, Burkeholder SB, Tarnowski J, Muniz LS, Melton MG, Palucka K. Safety and initial clinical efficacy of a dendritic cell (DC) vaccine in locally advanced, triple-negative breast cancer (TNBC) patients (pts). In: Annual meeting of the American-Society-of-Clinical-Oncology (ASCO), vol. 34. Chicago, IL. 2016. p. 1068.

164. Zhang P, Yi S, Li X, Liu R, Jiang H, Huang Z, Liu Y, Wu J, Huang Y. Preparation of triple-negative breast cancer vaccine through electrofusion with day-3 dendritic cells. PLoS ONE. 2014;9:e102197.

165. Huang Y, Long MJ, An J, Tang M, Liu RB. Dendritic cells-based vaccine to inhibit triple-negative breast cancer cells proliferation. In: Annual meeting of the American-Society-of-Clinical-Oncology (ASCO), vol. 34. Chicago, IL. 2016. p. e12566.

166. Ghiringhelli F, Apetoh L, Tesniere A, Aymeric L, Ma Y, Ortiz C, Vermaelen K, Panaretakis T, Mignot G, Ullrich E, et al. Activation of the NLRP3 inflammasome in dendritic cells induces IL-1 beta-dependent adaptive immunity against tumors. Nat Med. 2009;15:1170-8.

167. Mattarollo SR, Loi S, Duret H, Ma Y, Zitvogel L, Smyth MJ. Pivotal role of innate and adaptive immunity in anthracycline chemotherapy of established tumors. Cancer Res. 2011;71:4809-20.

168. Gonzalez-Angulo AM, Iwamoto T, Liu S, Chen H, Do KA, Hortobagyi GN, Mills GB, Meric-Bernstam F, Symmans WF, Pusztai L. Gene expression, molecular class changes, and pathway analysis after neoadjuvant systemic therapy for breast cancer. Clin Cancer Res. 2012;18:1109-19.

169. Pelekanou V, Carvajal-Hausdorf DE, Altan M, Wasserman B, CarvajalHausdorf C, Wimberly H, Brown J, Lannin D, Pusztai L, Rimm DL. Effect of neoadjuvant chemotherapy on tumor-infiltrating lymphocytes and PD-L1 expression in breast cancer and its clinical significance. Breast Cancer Res. 2017;19:91.

170. Garcia-Martinez E, Gil GL, Benito AC, Gonzalez-Billalabeitia E, Conesa MA, Garcia Garcia T, Garcia-Garre E, Vicente V, de la Pena FA. Tumorinfiltrating immune cell profiles and their change after neoadjuvant chemotherapy predict response and prognosis of breast cancer. Breast Cancer Res. 2014;16:488.

171. Park SJ, Namkoong H, Doh J, Choi JC, Yang BG, Park Y, Chul Sung Y. Negative role of inducible PD-1 on survival of activated dendritic cells. J Leukoc Biol. 2014;95:621-9.

172. Yuan XL, Xiao Y, Kuo WL, Yu DH. Immunogenic chemotherapy synergize PD-1 blockade by enhancing dendritic cells infiltration in triplenegative breast cancer (TNBC). In: AACR 107th annual meeting on bioinformatics and systems biology, vol. 76. New Orleans, LA. 2016.

173. Wang X, Ren J, Zhang J, Yan Y, Jiang N, Yu J, Di L, Song G, Che L, Jia J, et al. Prospective study of cyclophosphamide, thiotepa, carboplatin 
combined with adoptive DC-CIK followed by metronomic cyclophosphamide therapy as salvage treatment for triple negative metastatic breast cancers patients (aged <45). Clin Transl Oncol. 2016;18:82-7.

174. Panowski S, Bhakta S, Raab H, Polakis P, Junutula JR. Site-specific antibody drug conjugates for cancer therapy. MAbs. 2014;6:34-45.

175. Sussman D, Smith LM, Anderson ME, Duniho S, Hunter JH, Kostner $H$, Miyamoto JB, Nesterova A, Westendorf L, Van Epps HA, et al. SGN-LIV1A: a novel antibody-drug conjugate targeting LIV-1 for the treatment of metastatic breast cancer. Mol Cancer Ther. 2014;13:2991-3000.

176. Cardillo TM, Govindan SV, Sharkey RM, Trisal P, Arrojo R, Liu D, Rossi EA, Chang CH, Goldenberg DM. Sacituzumab govitecan (IMMU-132), an anti-Trop-2/SN-38 antibody-drug conjugate: characterization and efficacy in pancreatic, gastric, and other cancers. Bioconjug Chem. 2015;26:919-31.

177. Bardia A, Mayer IA, Diamond JR, Moroose RL, Isakoff SJ, Starodub AN, Shah NC, O'Shaughnessy J, Kalinsky K, Guarino M, et al. Efficacy and safety of Anti-Trop-2 antibody drug conjugate sacituzumab govitecan (IMMU-132) in heavily pretreated patients with metastatic triple-negative breast cancer. J Clin Oncol. 2017;35:2141-8.

178. Cardillo TM, Sharkey RM, Rossi DL, Arrojo R, Mostafa AA, Goldenberg DM. Synthetic lethality exploitation by an anti-Trop-2-SN-38 antibodydrug conjugate, IMMU-132, plus PARP inhibitors in BRCA1/2-wild-type triple-negative breast cancer. Clin Cancer Res. 2017;23:3405-15.

179. Bendell J, Saleh M, Rose AA, Siegel PM, Hart L, Sirpal S, Jones S, Green J, Crowley E, Simantov R, et al. Phase I/II study of the antibody-drug conjugate glembatumumab vedotin in patients with locally advanced or metastatic breast cancer. J Clin Oncol. 2014;32:3619-25.

180. Yardley DA, Weaver R, Melisko ME, Saleh MN, Arena FP, Forero A, Cigler T, Stopeck A, Citrin D, Oliff I, et al. EMERGE: a randomized phase II study of the antibody-drug conjugate glembatumumab vedotin in advanced glycoprotein NMB-expressing breast cancer. J Clin Oncol. 2015:33:1609-19.

181. Damelin M, Bankovich A, Bernstein J, Lucas J, Chen L, Williams S, Park A, Aguilar J, Ernstoff E, Charati M, et al. A PTK7-targeted antibody-drug conjugate reduces tumor-initiating cells and induces sustained tumor regressions. Sci Transl Med. 2017;9:eaag2611. https://doi.org/10.1126/ scitransImed.aag2611.

182. Dioufa N, Clark AM, Ma B, Beckwitt CH, Wells A. Bi-directional exosome-driven intercommunication between the hepatic niche and cancer cells. Mol Cancer. 2017;16:172. https://doi.org/10.1186/s1294 3-017-0740-6

183. Kim JE, Cho NH. Cancer-associated fibroblast (CAF)-derived exosome may mediate breast cancer progression by reducing exosomal microRNAs. Eur J Cancer. 2014;50:S61.

184. Clark DJ, Fondrie WE, Liao ZP, Hanson PI, Fulton A, Mao L, Yang AJ. Redefining the breast cancer exosome proteome by tandem mass tag quantitative proteomics and multivariate cluster analysis. Anal Chem. 2015:87:10462-9.

185. Georgoulia NE, Iliopoulos D, Mitchison TJ. Characterization of an exosome-associated apoptosis-inducing activity produced by triple negative breast cancer cells. In: Cancer research, vol. 72. 2012. p. P6-06-02.

186. Riches A, Campbell E, Borger E, Powis S. Regulation of exosome release from mammary epithelial and breast cancer cells_-a new regulatory pathway. Eur J Cancer. 2014;50:1025-34.

187. O'Loghlen A. Role for extracellular vesicles in the tumour microenvironment. Phil Trans R Soc B Biol Sci. 2018;372.

188. Zha QB, Yao YF, Ren ZJ, Li XJ, Tang JH. Extracellular vesicles: an overview of biogenesis, function, and role in breast cancer. Tumour Biol. 2017;39:1010428317691182. https://doi.org/10.1177/101042831769118 2.

189. Jia YL, Chen YX, Wang QC, Jayasinghe U, Luo X, Wei Q, Wang J, Xiong $\mathrm{HC}$, Chen C, Xu B, et al. Exosome: emerging biomarker in breast cancer. Oncotarget. 2017:8:41717-33.

190. Yu DD, Wu Y, Shen HY, Lv MM, Chen WX, Zhang XH, Zhong SL, Tang JH, Zhao JH. Exosomes in development, metastasis and drug resistance of breast cancer. Cancer Sci. 2015;106:959-64.

191. Harding CV, Heuser JE, Stahl PD. Exosomes: looking back three decades and into the future. J Cell Biol. 2013;200:367-71.
Ready to submit your research? Choose BMC and benefit from:

- fast, convenient online submission

- thorough peer review by experienced researchers in your field

- rapid publication on acceptance

- support for research data, including large and complex data types

- gold Open Access which fosters wider collaboration and increased citations

- maximum visibility for your research: over 100M website views per year

At BMC, research is always in progress.

Learn more biomedcentral.com/submissions 